
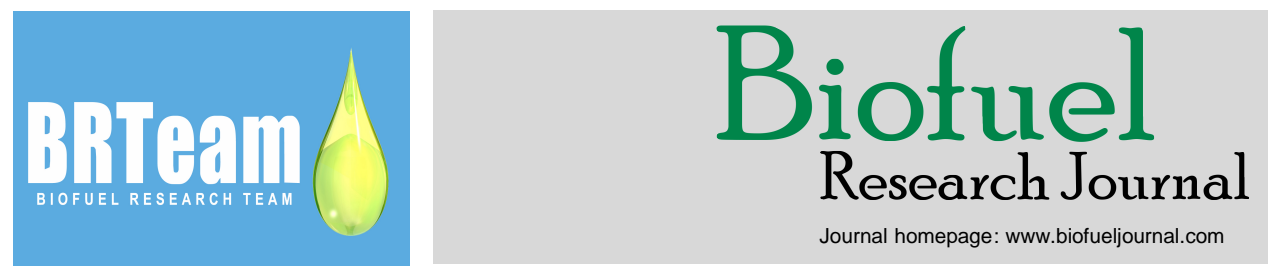

Journal homepage: www.biofueljournal.com

Review Paper

\title{
Exploitation alternatives of olive mill wastewater: production of value-added compounds useful for industry and agriculture
}

\author{
Pablo M. Ahmed ${ }^{1}$, Pablo M. Fernández ${ }^{2,3}$, Lucía I. C. de Figueroa ${ }^{2,4}$, Hipólito F. Pajot ${ }^{2,3, *}$
}

${ }^{1}$ Instituto de Tecnología Agroindustrial del Noroeste Argentino (ITANOA), Consejo Nacional de Investigaciones Científicas y Técnicas (CONICET), Estación

Experimental Agroindustrial Obispo Colombres (EEAOC), Av. William Cross 3150 (T4101XAC), Las Talitas, Tucumán, Argentina.

${ }^{2}$ Planta Piloto de Procesos Industriales Microbiológicos (PROIMI-CONICET), Av. Belgrano y Caseros (T4000INI), S M de Tucumán, Tucumán, Argentina.

${ }^{3}$ Facultad de Ciencias Exactas y Naturales, Universidad Nacional de Catamarca. Avenida Belgrano 300 (4700), SFV de Catamarca, Catamarca, Argentina.

${ }^{4}$ Microbiología Superior, Facultad de Bioquímica, Química y Farmacia, Universidad Nacional de Tucumán, Ayacucho 471 (T4000INI), S M de Tucumán,

Tucumán, Argentina.

\section{HIGHLIGHTS}

$>$ Olive mill wastewater (OMWW) can be exploited as feedstock for production of high value-added commodities.

$>$ An overview on potential uses of OMWW and related valorization strategies is presented.

$>$ A multifaceted approach integrating sustainable management and biorefinery concept is needed. - Valorization of various waste streams including OMWW is the main challenge faced by olive oil industry.

\section{GRAPHICAL ABSTRACT}

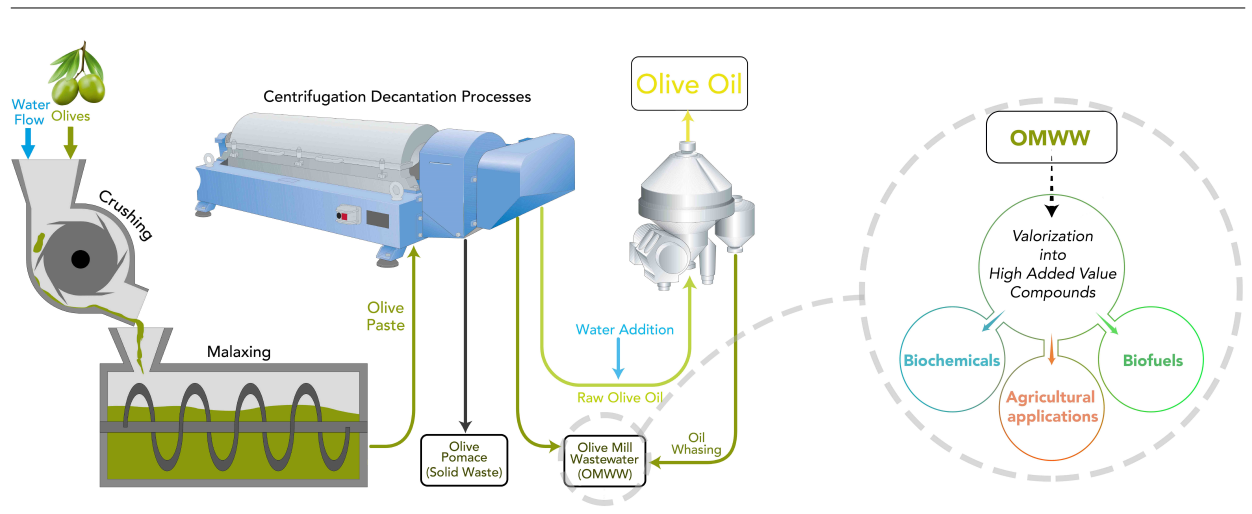

\section{ARTICLE INFO}

\section{Article history:}

Received 25 January 2019

Received in revised form 15 April 2019

Accepted 16 April 2019

Available online 1 June 2019

\section{Keywords:}

Olive mill wastewater

Bioconversion

Valorization and recycling

Sustainable managemen

Value-added compounds

Biorefinery

\begin{abstract}
Countries producing olive oil generate a considerable amount of olive mill wastewater (OMWW), one of the most harmful agroindustrial effluents with a powerful polluting capacity. In fact, owing to its high pollution load, this effluent is extremely toxic to the whole soil-air-water ecosystem as well as to the living organisms inhabiting it (i.e., plants, animals, aquatic organisms, microorganisms, etc.). Currently, OMWW is discarded but since it includes carbohydrates, organic acids and mineral nutrients, as well as elevated contents of phenolics and other natural antioxidants compounds, it could be considered as a potential source of high value-added natural products. Therefore, the valorization of different waste streams including OMWW into fine biochemicals and the recovery of valuable metabolites via biotechnological processes is probably the main challenge faced by the olive oil industry. In light of that, the aim of the present review article is to summarize the state-of-the-art in relation to the exploitation possibilities and the use of OMWW to generate added-value compounds of great significance for the biofuel, pharmaceutical, cosmetic, chemical, food, and agriculture industries. Valorization of this significant waste steam in particular through a biorefinery platform could substantially enhance the environmental sustainability aspects of the whole industry while simultaneously contributing to the improvement of its economic viability.
\end{abstract}

(C) 2019 BRTeam. All rights reserved.

* Corresponding author at: Tel.: +54 93814344888

E-mail address: hpajot@proimi.org.ar ; hipolito_pajot@yahoo.com

Please cite this article as: Ahmed P.M., Fernández P.M., Figueroa L.I.C., Pajot H.F. Exploitation alternatives of olive mill wastewater: production of valueadded compounds useful for industry and agriculture. Biofuel Research Journal 22 (2019) 980-994. DOI: 10.18331/BRJ2019.6.2.4 


\section{Contents}

1. Introduction.

2. Olive oil.

2.1. Production and consumption.

2.2. Types and designations......

3. Olive mill wastewater; main liquid residue from the olive oil industry

3.1. Composition and characteristics...

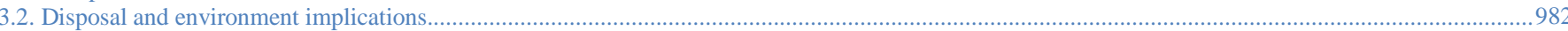

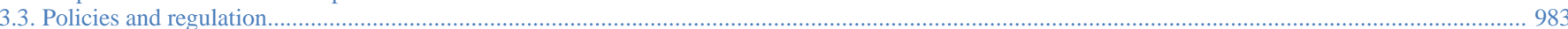

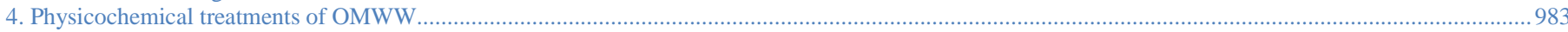

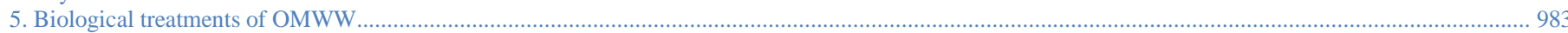

6. Valorization and biotransformation of OMWW into high added-value compounds................................................................................................... 983

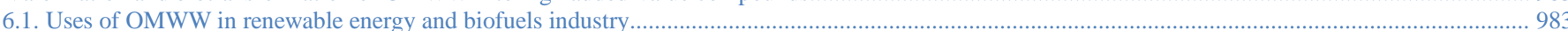

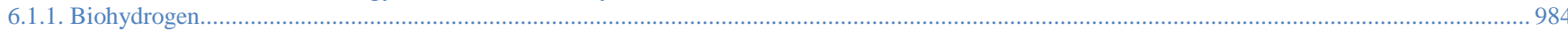

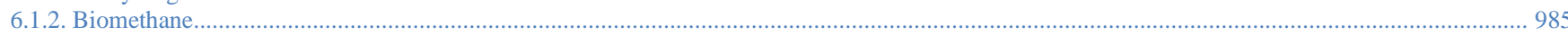

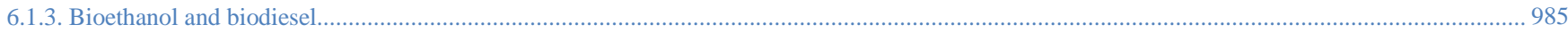

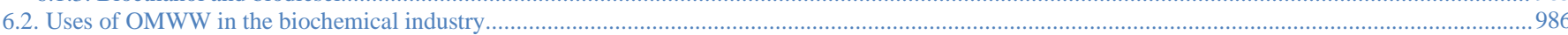

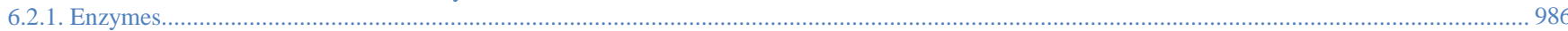

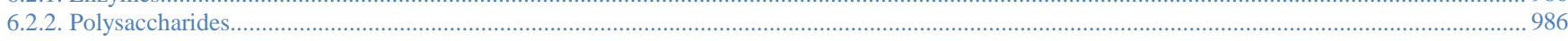

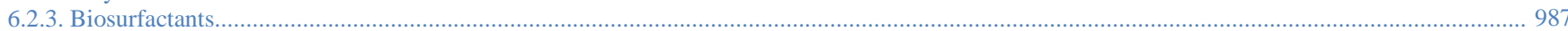

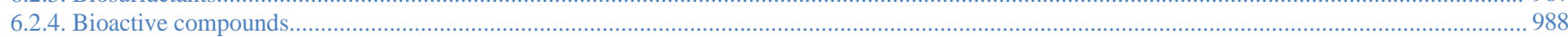

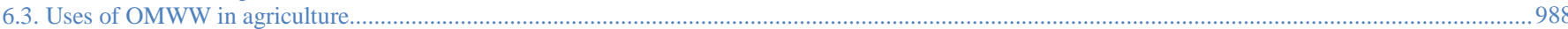

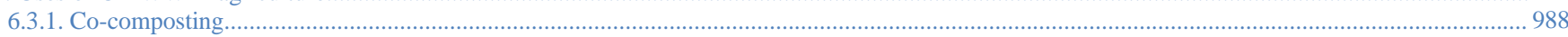

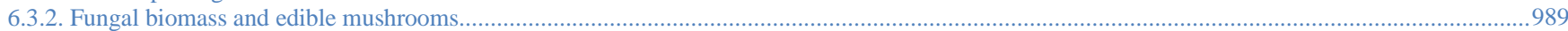

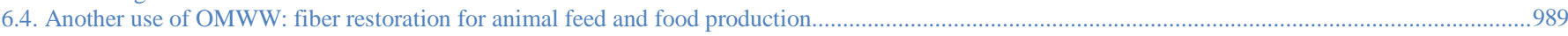

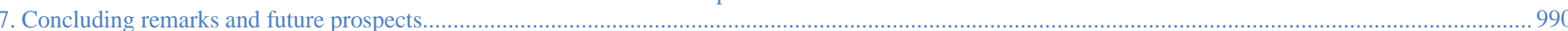

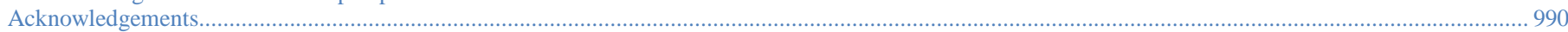

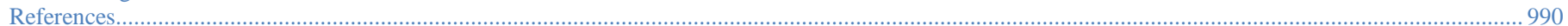

\section{Introduction}

Valorization and recycling constitute new concepts which are increasingly necessary worldwide. Typically, by-products, wastes, and effluents from fruit and vegetable processing consist of high amounts of proteins, sugars, and lipids along with peculiar aromatic and aliphatic compounds; thus, they could be considered as cheap and abundant raw materials for the synthesis of valueadded chemicals and biomaterials (Federici et al., 2009; Murthy and Naidu, 2012).

In relation to olive oil production, the chief concern is to find eco-friendly and economically viable solutions for the disposition and management of olive mill wastewater (OMWW). Considerable quantities of OMWW are produced during the manufacture of olives by the traditional milling and pressing processes, generating 1-2 $t$ of OMWW during the processing of $1 \mathrm{t}$ of olives (Paraskeva and Diamadopoulos, 2006). OMWW is a stable emulsion composed of vegetation water of olives, washing and process water, soft tissues from the olive pulp, and traces of olive. In many cases, direct disposal of olive mill effluents into lakes, rivers, and water streams has resulted in disastrous environmental consequences due to their high pollutant capacity (Yay et al., 2012).

Treatment of this agro-industrial effluent involves large capital investments and the installation of operating units that are of limited efficiency due to the high organic loads (chemical oxygen demand-COD- and biological oxygen demand-BOD). Moreover, the presence of organic and inorganic polluting substances makes this waste stream toxic to bacteria and other microorganisms used in biological treatments (El-Abbassi et al., 2012). However, the overall outlook is not completely discouraging and there are evidences highlighting the use of OMWW as an economic resource. In this sense, several studies have indicated that OMWW could be recycled and used as starting material to obtain profitable compounds such as antioxidants, enzymes, biogas, soil conditioners, feed and food, and fertilizers (Kourmentza et al., 2017; Gullón et al., 2018).

The present article critically reviews and discusses alternative approaches to valorize OMWW by transforming its constituents through various valorization strategies into high value-added commodities.

\section{Olive oil}

\subsection{Production and consumption}

Olive oil is widely consumed, with volumes rising steadily since 2005 (Aggoun et al., 2016). Olive farming and the olive oil industry are both economically and socially relevant, especially in the Mediterranean countries where about $98 \%$ of the world's olive oil is produced with an estimated production of above $15 \mathrm{M} \mathrm{m}^{3} / \mathrm{yr}$ (Ntougias et al., 2015). The most important olive oil producing country is Spain, followed by Italy, Greece, Turkey, Tunisia, Portugal, Morocco, and Algeria (Dourou et al., 2016). Outside the Mediterranean region, olives are cultivated in the Middle East, USA, Argentina, and Australia (Aparicio and Harwood, 2013).

In terms of demand, the consumption of olive oil in traditional markets is well known and deeply rooted in the populations` eating habits (Mili, 2006). Among traditional consumers of olive oil, Greece leads the ranking worldwide with an annual per capita consumption of $24 \mathrm{~L}$, followed by Spain and Italy with 14 and $12 \mathrm{~L}$, respectively (International Olive Council, 2017)

\subsection{Types and designations}

The olive oil from the olive tree Olea Europaea L. can be obtained solely by mechanical procedures or physical methods under certain conditions, especially thermal ones. These treatments do not lead to alterations to the oil and only include washing, decantation, centrifugation, and filtration (Dourou et al., 2016). One of the widely used procedures for olive oil extraction includes a traditional pressing method comprising a three-phase system that yields olive oil, a solid waste called olive pomace, and a liquid residue known as OMWW (Fig. 1). 


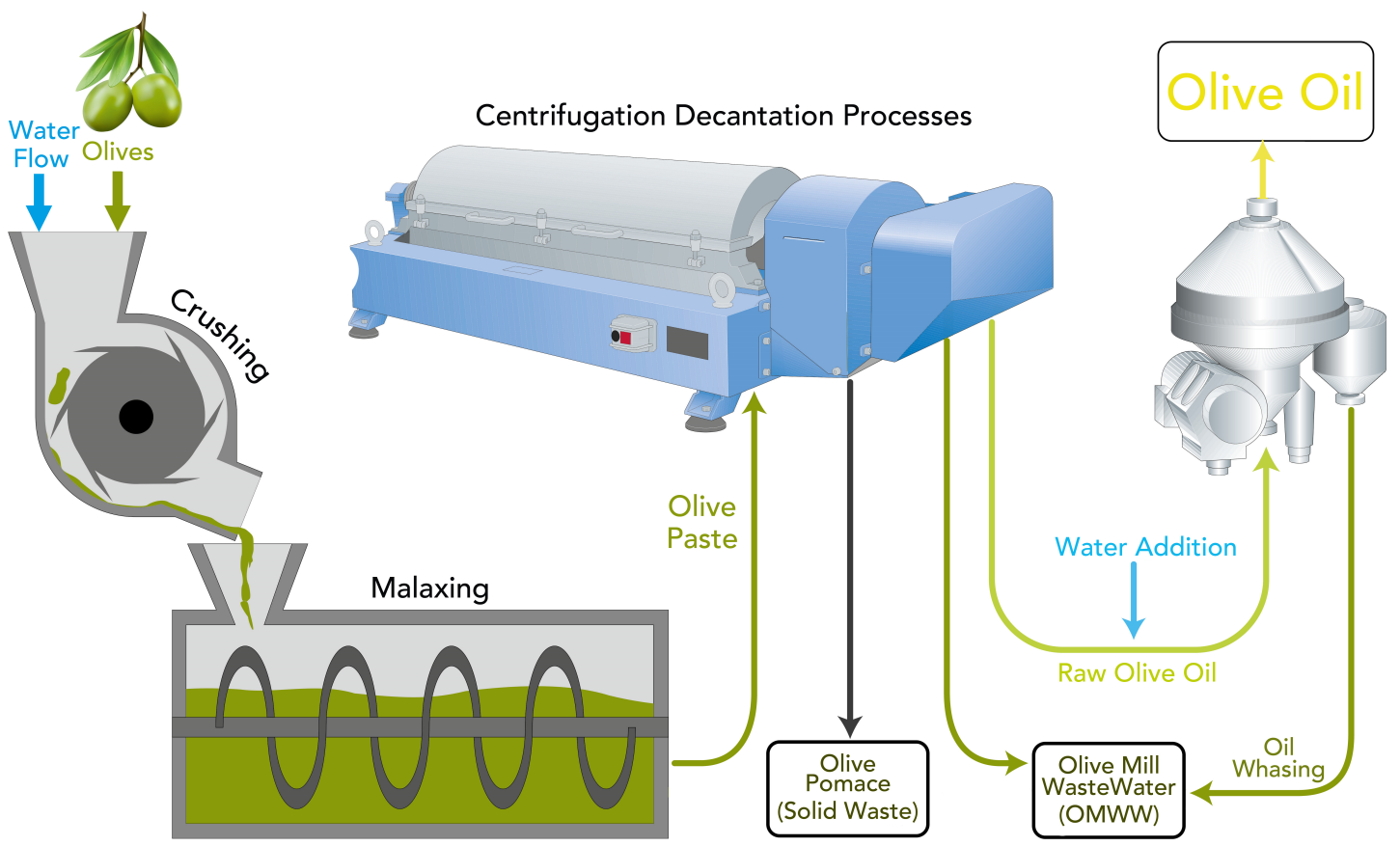

Fig. 1. Flowchart of obtaining olive oil through the three-phase procedure yielding three fractions: olive oil, olive pomace (solid residue), and OMWW.

Oil from olives are called virgin olive oil and, according to their acidity, the International Olive Council classifies them as:

-Extra virgin olive oil: with maximum purity and low free acidity of up to 0.8 g oleic acid/100 g oil.

-Virgin olive oil: with free acidity below or equal to $2 \mathrm{~g}$ oleic acid/100 $\mathrm{g}$ oil.

-Ordinary virgin olive oil: with free acidity no higher than $3.3 \mathrm{~g}$ oleic acid/100 g oil.

\section{Olive mill wastewater; main liquid waste stream of the olive oil industry}

The type, quality, and quantity of residues originated during oil extraction or olive fruit treatment depend not only on variety, maturity of olives, and region of origin of the olive trees but also on the extractive technology used (Roig et al., 2006). The methods used for olive oil extraction include discontinuous (pressing) or continuous (centrifuging) processes with the former regarded as the oldest and most extensive system for processing olives in both traditional mills and modern industries. Although this method generates a small volume of OMWW (up to $60 \mathrm{~L} / 100 \mathrm{~kg}$ olives), the wastewater has a higher COD compared to the OMWW produced by other processes (Di Giovacchino et al., 2002). As for the continuous olive oil extraction method, an industrial decanter is used to separate the phases obtained by centrifugation. There are two centrifugation systems, namely three-phase and two-phase systems that differ in the number of the end fractions generated (Roig et al., 2006). The continuous three-phase system produces a solid waste called olive husk or olive pomace and two liquid phases, i.e., oil and OMWW, while the two-phase technology separates the olive paste into two fractions: olive oil and a semi-solid residue known as two-phase olive-mill waste (TPOMW), a mixture of olive husk and OMWW. The continuous three-phase decanter presents some advantages like complete automation, better oil quality, and smaller area needed, however, it also presents some inconveniences such as expensive installation, greater energy consumption, and warm water addition, producing a larger quantity of OMWW (80-120 L/100 kg olives). In fact, the two-phase extraction process has been labeled as "ecological" because of reduced water consumption (Roig et al., 2006; Kapellakis et al., 2008).
Nevertheless, the resulting TPOMW has peculiar physico-chemical properties, it is generated in considerable quantities (10 L/100 kg olives), and is difficult to manage because its pollutants are more concentrated (Dermeche et al., 2013).

According to the International Olive Oil Council, pressing processes are usually used for olive oil extraction and significantly more or less water is required depending on the system employed (Therios, 2009). Even though traditional pressing is a relatively obsolete technology, it is still in use by various olive oil producers (Roig et al., 2006).

\subsection{Composition and characteristics}

The characteristics of OMWW are variable depending on geographic localtion of olives, type and maturity, method of extraction, climatic conditions, cultivation/processing procedures, and process mode (batch or continuous) involved in obtaining oil, etc. (Fountoulakis et al., 2002; Paraskeva and Diamadopoulos, 2006). This effluent is harmful to sewage treatment plants due to the large amounts of organic and suspended matters, and especially because of its oil content (Rytwo et al., 2013). OMWW usually contains high CODs, BODs, as well as elevated amounts of total phenols, carbohydrates, polysaccharides, fatty acids, polyalcohols, pectins, and tannins (Lesage-Meessen et al., 2001). The typical brownish-black color of OMWW is ascribed to the presence of polymeric phenols. These substances represent a lignin-like structure and constitute the most resistant fraction of this waste stream (Hamdi, 1993). In addition to its high-polluting power, OMWW usually exhibits a high level of phytotoxic and antibacterial activity due to the presence of various phenolic compounds, making it difficult to treat using biological technologies and soil microbial communities (Karpouzas et al., 2010; Ouzounidou et al., 2012).

\subsection{Disposal and environment implications}

OMWW is produced in huge quantities around the world annually, and its unsafe disposal leads to water, air, and land pollution in the proximity of olive oil processing units.

The large volumes of OMWW generated and the brief period of olive oil production, between November and March in the Mediterranean olivesgrowing countries, aggravate the environmental damage caused when these 
effluents are disposed of into the environment without treatment (Aviani et al., 2012; Ntougias et al., 2013). Dumping of untreated OMWW causes severe environmental impairments ranging from altering the color of natural water sources and toxicity to aquatic life to contamination of surface and ground waters, soil quality adulteration, cytotoxicity, phytotoxicity, and nauseous odor (Dermeche et al., 2013).

OMWW discharge into soil has direct detrimental effects not only on plant growth and microbial metabolism but also on the physicochemical properties of the soil (Paredes et al., 1987). Soils could have differences in their intrinsic buffering capability depending on their origin and thus, may react differently to the same applied disturbance. However, it is important to highlight the fact that, due to the high concentration of recalcitrant compounds in OMWW, its direct use in fertigation, for instance, can inhibit plant seed germination. Moreover, oil compounds present in these streams may cause increased soil hydrophobicity and diminished water retention and infiltration rates (Kavvadias et al., 2010; Piotrowska et al., 2011). Although the impact of OMWW application on soil properties seems to be the result of contrary effects, in agreement with the balance between beneficial and toxic organic and inorganic compounds, the main conclusions of the research in this field confirm that the direct application of untreated OMWW has severe consequences in the long term. However, depending on the OMWW dilution rate and by controlling its application in soils, the above-mentioned negative effects of this wastewater could be reduced and its application could be beneficial (Magdich et al., 2012).

Several compounds dissolved in OMWW have influences on surface waters: 1) reduced sugars can stimulate microbial respiration lowering dissolved oxygen availability; 2) high concentrations of dark phenolics can alter the color of natural water resources (streams and rivers); and 3) lipids may form an impenetrable layer on the receiving water-surface blocking out sunlight and oxygen, thus inhibiting plant growth and favoring alga proliferation (Kapellakis et al., 2006). Therefore, the disposal of OMWW in sea-, river- or groundwater has resulted in serious concerns. It has been demonstrated that direct OMWW dumping into marine environments could cause pre-pathological alterations in marine organisms. The results obtained have shown the occurrence of structural deterioration in the aquatic populations due to the polluting effects of OMWW as well as decreases in water capability of reducing the impact through internal mechanisms of self-purification (Danellakis et al., 2011; Pavlidou et al., 2014). There are some cases where evaporation ponds or lagoons were built to contain this wastewater; however, they were rarely a suitable alternative to stabilize and safely accommodate this liquid waste. In most instances, the bottom of these ponds was permeable, thus leading to the introduction of OMWW into nearby systems such as agricultural soils and adjoining surface- and groundwater. In fact, it has been reported that OMWW spreading might increase phenolic compounds in soil and groundwater during the active period of olive factories (Koutsos et al., 2018).

OMWW can also contaminate the air if it is stored in open tanks or disposed of into large fields. It can undergo fermentation and emit methane and other pungent gases such as hydrogen sulfide, creating unpleasant odor pollution (Niaounakis and Halvadakis, 2006).

\subsection{Policies and regulation}

Pollution awareness and policies have played a minor role in finding uses for OMWW; nevertheless, there is a collective concern throughout the world with respect to environmental pollution caused by this kind of agro-industrial wastewaters. The United States Environmental Protection Agency (EPA) developed and implemented related policies and regulations more than a decade ago (Singh, 2006), while the European Commission established laws to influence the environmental regulations and technical aspects of industrial OMWW discharge in all olive oil-producing countries. In Spain, the government has prohibited the discharge of OMWW into receiving media and the two-phase olive oil extraction method (yielding olive wet pomace as the sole residue) is currently being used to decrease water requirements and consequently, the amounts of wastes generated (Azbar et al., 2004). In Italy, rules and regulations exist governing OMWW dumping in soils amenable to agricultural practices (Rana et al., 2003) while through a special permission obtained some time ago, Portugal allows land spreading of this wastewater (decree-law no. 236/98) (Cheng, 2006).

In Greek legislations, there are no specific guidelines about OMWW discharge. Moreover, laws concerning land applications and recycling of these effluents are yet to be adopted (Azbar et al., 2004; Kapellakis et al., 2006).

Other olive producing countries lack wastewater disposition policies but employ sustainable practices with this respect. For instance, in Tunisia, OMWW produced every year is collected and poured into large concrete evaporation reservoirs adjacent to wastewater treatment plants (Ammar anc Ben Rouina, 1999). In Turkey, olive oil industries are generally located in the west and south of the territory and the main obstacle for safe OMWW disposal is that factories are small and scattered throughout a large geographical area. The Turkish government is yet to specifically regulate the release of OMWW (Yay et al., 2012).

The European wastewater policy necessitates that only OMWW treated in accordance with relevant quality standards and the provisions required by Directive on Urban Wastewater Treatment (1991) (Directive 271/91, later amended by Directive 15/98) could be discharged into receiving waters bodies.

\section{Physicochemical treatments of OMWW}

The most relevant physicochemical treatments of OMWW include methods such as evaporation, reverse osmosis, ultrafiltration, coagulation, oxidation, thermal drying, and advanced oxidation technologies such as ozonation, Fenton processes, and electrochemical oxidization (Mert et al. 2010; Scoma et al., 2011).

Although several physicochemical processes are used for OMWW treatment, these are not completely successful. Their implementation is often associated with large-scale feasibility and cost-efficiency issues which may be further accompanied by other technical or environmental problems related to emission of air pollutants, membrane fouling, toxicity induced by radical species, and the formation of large quantities of toxic sludge, among others.

\section{Biological treatments of OMWW}

Among the biological treatments of OMWW, anaerobic digestion has been proposed as a promising technology for olive residues management to produce energy (biogas). However, numerous obstacles still need to be overcome such as growth inhibition of methanogenic archaea by phenolic compounds, low pH, low nitrogen concentration, etc. (Orive et al., 2016). Other biological alternatives are aerobic methods and include composting as well as treatments with fungi, bacteria, and algae (Pinto et al., 2003; Dhouib et al., 2006; Tziotzios et al., 2007; Chowdhury et al., 2013). The success of each method depends on the technology used. Nonetheless, it should be noted that any biological treatment alternatives should constitute a sustainable strategy for the management of OMWW, i.e., through the exploitation of the nutritive potential of this waste stream for the production of various high added-value compounds.

\section{Valorization and biotransformation of OMWW into high added- value compounds}

OMWW can be considered as a resource to be recycled and recovered. Present-day strategies aim at cleaner production methods or practices that consider not only olives and olive oil economic production but also the potentially beneficial uses of their residues. The bio-based exploitation alternatives for OMWW to obtain added-value compounds are summarized in Figure 2.

\subsection{Uses of OMWW in renewable energy and biofuels industry}

It is obvious that the need to reduce dependence on conventional fossil fuels in favor of new alternative energy resources is a top global priority. Green energies could effectively contribute to mitigation of greenhouse gases emissions and their consequent unfavorable impacts including global warming and climate change (Hill, 2009). In this sense, OMWW is a promising raw material for bioenergy and biofuel production owing to its low to moderate contents of nitrogen, sugars, volatile acids, polyalcohols, and fats (Dermeche et al., 2013). 


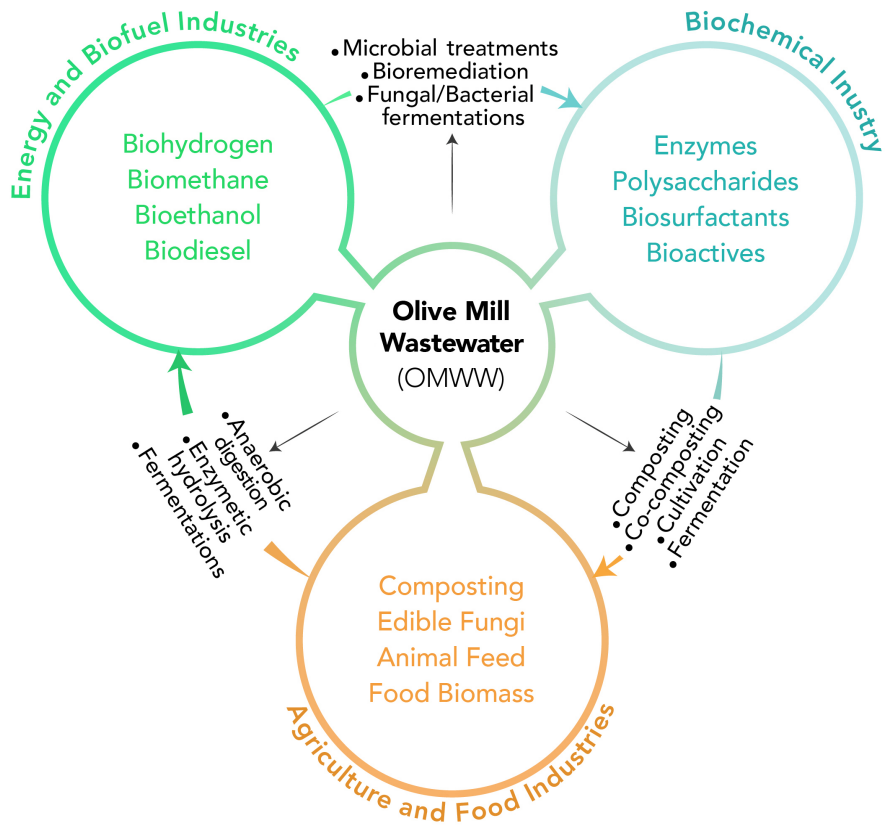

Fig. 2. Alternatives for microbial valorization and potential uses of OMWW.

\subsubsection{Biohydrogen}

Biohydrogen (bio- $\mathrm{H}_{2}$ ) is considered as a renewable energy carrier with the capacity to supply the forthcoming energy demands and with the potential to replace fossil fuels. That is why it is acknowledged as the versatile fuel of the future (Kotay and Das, 2008). Bio- $\mathrm{H}_{2}$ production involves a wide range of reactions, including direct and indirect biophotolysis, photo-fermentation, and dark-fermentation. Moreover, bio- $\mathrm{H}_{2}$ can be produced by a large number of microorganisms (mainly bacteria) with distinctive physiological and metabolic features through single or combined catabolic pathways (Table 1). Certain microbial production processes involve the use of photosynthetic products by enzymes with either hydrogenase or nitrogenase activity as bio- $\mathrm{H}_{2}$-producing proteins (Kotay and Das, 2008) The low nitrogen content of OMWW makes it a favorable substrate for photo-fermentative bio- $\mathrm{H}_{2}$ production because high $\mathrm{NH}_{4}{ }^{+}$concentrations inhibit nitrogenase synthesis and activity (Uyar et al., 2012). However, numerous investigations stress on the fact that bio- $\mathrm{H}_{2}$ production by photosynthetic bacteria using OMWW as a substrate necessarily requires counteracting its inhibitory effects caused by the dark color of this wastewater. In order to overcome this problem, high dilution rates of OMWW has been proposed. Eroglu et al. (2004) studied bio- $\mathrm{H}_{2}$ production from diluted OMWW within the range of $1 \%$ to $20 \%(\mathrm{v} / \mathrm{v})$ using the photosynthetic bacterium Rhodobacter sphaeroides in column photobioreactors. With this agro-industrial wastewater as the sole substrate source, the authors reached a maximum bio- $\mathrm{H}_{2}$ production potential (HPP) of around $13.9 \mathrm{~L} / \mathrm{L}$ when the $2 \% \mathrm{OMWW}$-containing media was used. Later, the same researchers performed a comparative study with different samples of OMWW (diluted to $4 \% \mathrm{v} / \mathrm{v}$ ) from different olive oil factories in Anatolia and Turkey, and investigated bio- $\mathrm{H}_{2}$ production under anaerobic photo-fermentative conditions using $R$. sphaeroides O.U.001. They found a linear relationship between $\mathrm{C} / \mathrm{N}$ molar ratios and bio- $\mathrm{H}_{2}$ production capacities. Maximum HPP (20 L/L of OMWW) was recorded from the OMWW samples with the greatest organic content (mostly acetic, aspartic, and glutamic acids) and the highest $\mathrm{C} / \mathrm{N}$ molar ratio (Eroglu et al., 2009).

$R$. sphaeroides is the most investigated photo-fermentative bacterial species in bio- $\mathrm{H}_{2}$ production coupled with OMWW treatment. Eroglu et al. (2011) studies bio- $\mathrm{H}_{2}$ production linked to OMWW photodegradation by R. sphaeroides O.U.001 strain using diluted cultures of this wastewater (2\% v/v) supplemented with iron and molybdenum. These two metals were selected because both are part of the nitrogenase enzyme complex involved in photosynthetic processes. The diluted iron-supplemented OMWW-based cultures not only showed a significantly increased production $(125 \mathrm{~mL}$ bio$\mathrm{H}_{2}$ vs. $62 \mathrm{~mL}$ obtained in the presence of molybdenum) but also yielded

Table 1.

General reactions of bio-hydrogen (bio- $\mathrm{H}_{2}$ ) production and main participating microorganisms. Modified from Dermeche et al. (2013).

\begin{tabular}{|c|c|c|}
\hline Variety of bio-hydrogen $\left(\right.$ bio- $\left.\mathrm{H}_{2}\right)$ production pathways & Microorganisms & References \\
\hline \multicolumn{3}{|c|}{ Bio- $\mathrm{H}_{2}$ production reactions in a single way } \\
\hline $\begin{array}{l}\text { Bio- } \mathrm{H}_{2} \text { production by dark fermentation } \\
\mathrm{C}_{6} \mathrm{H}_{12} \mathrm{O}_{6}+2 \mathrm{H}_{2} \mathrm{O} \rightarrow 2 \mathrm{CH}_{3} \mathrm{COOH}+2 \mathrm{CO}_{2}+4 \mathrm{H}_{2} \\
\mathrm{C}_{6} \mathrm{H}_{12} \mathrm{O}_{6} \rightarrow \mathrm{CH}_{3} \mathrm{CH}_{2} \mathrm{COOH}+\mathrm{CH}_{3} \mathrm{COOH}+\mathrm{CO}_{2}+\mathrm{H}_{2} \\
\mathrm{C}_{6} \mathrm{H}_{12} \mathrm{O}_{6} \rightarrow \mathrm{CH}_{3} \mathrm{CH}_{2} \mathrm{CH}_{2} \mathrm{COOH}+2 \mathrm{CO}_{2}+2 \mathrm{H}_{2}\end{array}$ & Heterotrophic bacteria (Clostridium sp.) & Lin et al. (2007); Kotay and Das (2008) \\
\hline $\begin{array}{l}\text { Bio- } \mathrm{H}_{2} \text { production by direct/indirect biophotolysis } \\
12 \mathrm{H}_{2} \mathrm{O} \rightarrow 12 \mathrm{H}_{2}+6 \mathrm{O}_{2}\end{array}$ & $\begin{array}{l}\text { Green micro algae (Chlamydomonas reinhardti) } \\
\text { Cyanobacteria (Anabaena } \mathrm{sp.)}\end{array}$ & Kotay and Das (2008) \\
\hline $\begin{array}{l}\text { Bio- } \mathrm{H}_{2} \text { production by photo-fermentation (photo decomposition of organic compounds) } \\
\mathrm{C}_{6} \mathrm{H}_{12} \mathrm{O}_{6}+6 \mathrm{H}_{2} \mathrm{O} \rightarrow 6 \mathrm{CO}_{2}+12 \mathrm{H}_{2}\end{array}$ & $\begin{array}{l}\text { Purple-phototropic (anaerobes photosynthetic) bacteria } \\
\text { (Rhodobacter sphaeroides, Rhodopseudomonas palustris) }\end{array}$ & $\begin{array}{l}\text { Kataoka et al. (1997); Mahyudin et al. } \\
\text { (1997); Tanisho et al. (1998) }\end{array}$ \\
\hline $\begin{array}{l}\text { Other single reaction of bio- } \mathrm{H}_{2} \text { production (from } \mathrm{CO} \text { ) } \\
\mathrm{CO}+\mathrm{H}_{2} \mathrm{O} \rightarrow \mathrm{H}_{2}+\mathrm{CO}_{2}\end{array}$ & Photosynthetic bacteria & $\begin{array}{l}\text { Kotay and Das (2008); Ena et al. } \\
\text { (2010); Eroglu et al. (2010) }\end{array}$ \\
\hline \multicolumn{3}{|c|}{ Bio- $\mathrm{H}_{2}$ production through combined ways } \\
\hline \multicolumn{3}{|l|}{ First Stage: Dark fermentation } \\
\hline $\begin{array}{l}\mathrm{C}_{6} \mathrm{H}_{12} \mathrm{O}_{6}+2 \mathrm{H}_{2} \mathrm{O} \rightarrow 2 \mathrm{CH}_{3} \mathrm{COOH}+2 \mathrm{CO}_{2}+4 \mathrm{H}_{2} \\
\text { Second Stage: Photo-fermentation } \\
2 \mathrm{CH}_{3} \mathrm{COOH}+4 \mathrm{H}_{2} \mathrm{O} \rightarrow+4 \mathrm{CO}_{2}+8 \mathrm{H}_{2}\end{array}$ & $\begin{array}{l}\text { Facultative anaerobes bacteria } \\
\text { Photosynthetic bacteria (Rhodobacter sphaeroides) }\end{array}$ & $\begin{array}{l}\text { Kotay and Das (2008); Eroglu et al. } \\
\text { (2006) }\end{array}$ \\
\hline
\end{tabular}

Please cite this article as: Ahmed P.M., Fernández P.M., Figueroa L.I.C., Pajot H.F. Exploitation alternatives of olive mill wastewater: production of valueadded compounds useful for industry and agriculture. Biofuel Research Journal 22 (2019) 980-994. DOI: 10.18331/BRJ2019.6.2.4 
better wastewater treatment results by removing $48.1 \%$ of the initial COD value compared with the control reactor in which the maximum COD removal efficiency achieved was $30.2 \%$.

Ena et al. (2010) evaluated the purple bacteria Rhodopseudomonas palustris (strain 6A) for bio- $\mathrm{H}_{2}$ production using cylindrical (CPBR) and flat (FPBR) photobioreactors in both batch and semi-continuous conditions, under continuous light at $30{ }^{\circ} \mathrm{C}$. The bacterium was grown in a dry-Azolla and activated carbon pretreated OMWW (25\% v/v) and removed 80\% COD and $98 \%$ phenols. Successful bio- $\mathrm{H}_{2}$ production results were also obtained throughout the experiments. More specifically, during the lag-phase of growth, no hydrogen was produced in none of the photobioreactors; however, bio- $\mathrm{H}_{2}$ generation began at $406 \mathrm{~h}$ of culture, and final volumes of $0.53 \mathrm{~L}$ in the CPBR and $0.31 \mathrm{~L}$ in the FPBR were recorded in the batch regime. When this operation mode was compared with the semi-continuous mode, the latter showed a better performance with significantly higher bio- $\mathrm{H}_{2}$ production.

Other microorganisms have also been studied in photo-fermentative processes for bio- $\mathrm{H}_{2}$ production employing OMWW as a substrate. Faraloni et al. (2011) proposed a two-stage fermentation for bio- $\mathrm{H}_{2}$ photoproduction by the green microalga Chlamydomonas reinhardtii cultivated in OMWW diluted and pretreated by biofiltration with Azolla caroliniana and granular activated carbon as remediating agents. They observed that under sulfur-deprived conditions, $C$. reinhardtii metabolism was able to shift to bio- $\mathrm{H}_{2}$ production through the photosystem II-driven water splitting of this microalga as well as the fermentation of accumulated carbohydrates.

\subsubsection{Biomethane}

Effluents with high organic load concentrations can also be converted into methane $\left(\mathrm{CH}_{4}\right)$ and carbon dioxide $\left(\mathrm{CO}_{2}\right)$ in anaerobic digesters through the concerted actions of different microbial populations. The whole methanogenesis reaction may be summarized as follows $(\mathrm{Eq}$. 1)

Organic load (aqueous medium) + microbial resource

$$
\rightarrow \mathrm{CH}_{4}+\mathrm{CO}_{2}+\mathrm{NH}_{3}+\mathrm{H}_{2} \mathrm{~S}+\text { microbial biomass }+ \text { heat }
$$

Usually, methane production from OMWW involves aerobic or anaerobic pretreatment of this wastewater followed by a two-phase anaerobic digestion process. Fungi proved to be excellent candidates to pretreat OMWW prior to anaerobic digestion. Hamdi (1991) pretreated OMWW with Aspergillus niger and the amount of $\mathrm{CH}_{4}$ produced was twice higher in the subsequent anaerobic digestion. Borja et al. (1995) carried out a comparative kinetic study of the OMWW anaerobic digestion without pretreatment and pretreated by the fungus Aspergillus terreus. The results obtained demonstrated that the pretreatment applied influenced methane volumetric production, resulting in $1.1 \mathrm{~L}$ and $0.6 \mathrm{~L}$ $\mathrm{CH}_{4} / \mathrm{L}_{\mathrm{OMwW}} / \mathrm{d}$ for the reactors processing predigested and untreated OMWW, respectively. The aerobically pre-fermented effluent drastically reduced the levels of both phenolic compounds and biotoxicity while significantly increased $\mathrm{CH}_{4}$ production by up to $83 \%$.

During the first phase of the two-phase anaerobic digestion, macromolecules such as carbohydrates, proteins, and lipids are transformed by hydrolytic and acidogenic fermentative bacteria into simple organic compounds (sugars, volatile fatty acids, and amino acids) and intermediates such as volatile organic acids (mainly acetic, propionic, and butyric), alcohols (mainly ethanol), ketones (cetone), $\mathrm{CO}_{2}$, and hydrogen. In the second phase, through the interactions between methanogenic and acetogenic microorganisms, all these metabolites are metabolized and transformed into $\mathrm{CH}_{4}$ and $\mathrm{CO}_{2}$ (Moraes et al., 2015). Fezzani and Ben Cheikh (2010) carried out the two-phase anaerobic digestion of OMWW together with an olive mill solid waste using five semicontinuous digesters at mesophilic temperature $\left(37 \pm 2{ }^{\circ} \mathrm{C}\right)$. In the acidifierstage (first step), two of the five reactors were operated using a hydraulic retention time (HRT) ranging between 14 and $24 \mathrm{~d}$, and an organic loading rate (OLR) ranging from 5.54 to $14 \mathrm{~g} \mathrm{COD} / \mathrm{L} / \mathrm{d}$. The methanogenesis stage (second step) was conducted in the three remaining digesters at 18, 24 and $36 \mathrm{~d}$ of HRT, with OLRs ranging from 2.28 to $9.17 \mathrm{~g} \mathrm{COD} / \mathrm{L} / \mathrm{d}$. The results indicated that the volatile fatty acids (VFA) content was augmented by increasing HRT or feed concentration and the maximum values were obtained at the HRT of $24 \mathrm{~d}$, which corresponded to an OLR of $8.17 \mathrm{~g} \mathrm{COD/L/d}$. Their two-phase anaerobic digestion system let to the best methane productivity $\left(32 \mathrm{~L} / \mathrm{L}_{\mathrm{OMww}}\right)$ compared to those achieved with conventional one-phase anaerobic digesters (Fezzani and Ben Cheikh, 2007). This could be ascribed to the fact that the high levels of VFAs produced during the acidification step could be easily metabolized and biotransformed into $\mathrm{CH}_{4}$ and $\mathrm{CO}_{2}$ in the subsequent step.

Some researchers have studied other OMWW pretreatment alternatives prior to anaerobic digestion for biomethane production. Azbar et al. (2008) demonstrated that chemical pretreatment of OMWW by employing acids, followed by a coagulation-flocculation process using $\mathrm{Al}_{2} \mathrm{SO}_{4}, \mathrm{FeSO}_{4}$, and $\mathrm{FeCl}_{3}$, enhanced the anaerobic biodegradability of this agro-industria residue leading to $80 \%$ higher $\mathrm{CH}_{4}$ production compared with the untreated effluent.

OMWW co-digestion with other wastes such as poultry manure, slaughterhouse wastewaters, winery residues, and liquid cow manure has also been investigated, resulting in $\mathrm{CH}_{4}$ yields of more than $250 \mathrm{~L} / \mathrm{kg}$ COD (Gelegenis et al., 2007; Fountoulakis et al., 2008; Dareioti et al., 2010).

\subsubsection{Bioethanol and biodiesel}

The huge amounts of organic matters in OMWW also make it a suitable feedstock for ethanol and biodiesel production. However, it is necessary to remove or reduce its phenolic compounds in order to use its carbohydrate and lipid fractions to produce these biofuels. Massadeh and Modallal (2008) investigated the capability of a Pleurotus sajor-caju strain to degrade phenols in OMWW preconditioned by different treatments: $50 \%$ water-diluted and undiluted OMWW thermally processed at $100{ }^{\circ} \mathrm{C}$, and OMWW thermally processed and predigested with hydrogen peroxide $\left(\mathrm{H}_{2} \mathrm{O}_{2}\right)$. Results showed that the degradation of phenols with $P$. sajor-caju reached as high as 50\% for the thermally processed diluted OMWW, 53\% for the thermally processed OMWW pretreated with $\mathrm{H}_{2} \mathrm{O}_{2}$, and $58 \%$ for the thermally processed undiluted OMWW. The impact of this biological pretreatment was subsequently tested with the yeast Saccharomyces cerevisiae. According to the results obtained, pretreatment with $P$. sajor$c a j u$ led to enhanced ethanol production from OMWW. The highest ethanol yield of $14.2 \mathrm{~g} / \mathrm{L}$ was obtained after $48 \mathrm{~h}$ of fermentation using $50 \%$ diluted and thermally processed OMWW.

Sarris et al. (2014) also evaluated S. cerevisiae MAK-1 for simultaneous OMWW remediation and production of added-value compounds. Under aerated conditions in non-sterile shake-flask cultures, cultures in molassesbased media were supplemented with OMWW. No significant decreases in ethanol $(34.3 \mathrm{~g} / \mathrm{L})$ and biomass production $(7.3 \mathrm{~g} / \mathrm{L})$ were observed in comparison with the control experiments (i.e., cultures with no OMWW supplementation). Under similar but aerated bioreactor conditions, biomass production decreased $(5.7 \mathrm{~g} / \mathrm{L})$ while on the contrary; ethanol yield was notably enhanced (up to $41.8 \mathrm{~g} / \mathrm{L}$ ).

Some studies have also reported on the exploitation of olive oil liquid and solid by-products and their bioconversion to biodiesel. Yousuf et al. (2010) argued that Lipomyces starkeyi could be a promising yeast strain as a non-conventional source of oil and used it for the conversion of OMWW into lipids for biodiesel production. They demonstrated that the investigated yeast was capable of proliferating in the presence of undiluted OMWW, with no external organic compound supplementation requirements, and significant reduced both total organic carbon and total phenols contents of the wastewater. Nevertheless, when the OMWW was 50\% diluted by distilled water, polluting compounds were reduced and a significant increase in lipid yield was observed $(28.6 \%$ vs. $22.4 \%$ in the undiluted OMWW). The fatty acid profiles obtained showed a prevalence of oleic acid, demonstrating the potential of this yeast to store lipids suitable for (second-generation) biodiesel production.

Sarris et al. (2017) evaluated the cultivation of Yarrowia lipolytica on commercial glucose-supplemented media plus OMWW in high concentrations (i.e., high phenolic compounds quantities). Their results revealed the capability of the strain to grow and produce highly lipid enriched biomass and citric acid despite the high concentration of phenolic compounds present. Satisfactory citric acid quantities were produced in nitrogen-limited media while non-negligible biomass production was observed in carbon-limited media. The addition of OMWW in the medium favored the accumulation of storage lipids suggesting that OMWW seemed to be a "lipogenic" substrate. Both nitrogen and carbon-limited fermentations resulted in a remarkable discoloration and a non-negligible reduction of phenolic compounds in the media. In another investigation, $L$. starkeyi NRRL Y-11557 and Y. lipolytica strains also showed a noteworthy ability to accumulate lipids (15-25\%, w/w) when cultivated on OMWW- 
based media. Oleic acid and palmitic acid were the main fatty acids produced when the culture medium was enriched with OMWW as low-cost carbon source (Dorou et al., 2016).

Bellou et al. (2014) demonstrate the ability of Zygomycetes strains to grow on OMWW and bioconvert it into lipids containing polyunsaturated fatty acids in submerged cultures; while in parallel, phenolic compounds were also removed. In liquid media containing OMWW as the sole carbon source, the maximum cell mass produced, the maximum specific growth rate, as well as cell mass and lipid yields (60\% w/w) were almost unaffected in comparison with the control sample. Oleic and palmitic acids were the predominant fatty acids determined. Gamma-linolenic acid was found in high percentages (up to $17.7 \%, \mathrm{w} / \mathrm{w}$ ) in the lipidd produced by Zygorhynchus moelleri. Similarly, adaptation of $Y$. lipolytica in OMWW-based media favored the biosynthesis of cellular unsaturated fatty acids, principally oleic and palmitoleic acids (Papanikolaou et al., 2008).

\subsection{Uses of $O M W W$ in the biochemical industry}

The production of biochemicals by various microorganisms has a long history and continues to be one of the most interesting biotechnological alternatives to valorize OMWW. The synthesis of bio-based compounds from OMWW is doubly beneficial since it not only valorizes this low-cost waste stream as feedstock but also reduces the environmental damages caused by its natural discharge.

\subsubsection{Enzymes}

The biotechnological application of microbial enzymes has grown considerably over the last 20 years, especially with respect to the biotransformation of agro-industrial wastes (Gassara et al., 2010). Fungi are well-known microorganisms due to their ability to synthesize a wide range of biological catalysts that can be used in various industrial processes. Specifically, ligninolytic fungi constitute a powerful tool for OMWW degradation and detoxification since they have demonstrated their ability to remove recalcitrant compounds like the ones present in these effluents through the production of non-specific oxidative enzymes such as phenoloxidases, polyphenoloxidases, and peroxidases (Ntougias et al., 2013 and 2015). Table 2 shows examples of the production of ligninolytic enzymes coupled with OMWW bioremediation under several culture parameters and using different ligninolytic fungi.

Fenice et al. (2003) used an OMWW-based medium (2-fold diluted OMWW supplemented with $0.5 \%$ sucrose and $0.1 \%$ yeast extract) for the growth of Panus trigrinus CBS 577.79 with the consequent production of laccase (Lacc) and Manganese peroxidase (MnP). The highest activity levels achieved were $4600 \pm 98 \mathrm{U} / \mathrm{L}$ and $370 \pm 15 \mathrm{U} / \mathrm{L}$, respectively, in a stirred-tank reactor and $4300 \pm 23 \mathrm{U} / \mathrm{L}$ and $410 \pm 22 \mathrm{U} / \mathrm{L}$, respectively, in an airlift reactor.

Koutrotsios et al. (2016) evaluated the suitability of OMWW $(12.5 \%, 25 \%$, and $50 \% \mathrm{v} / \mathrm{v}$ ) as a substrate for the production of Lacc and MnP by the fungus Hericium erinaceus. During OMWW bio-treatment, the enzymes profiles obtained revealed a maximum Lacc activity of $134 \mathrm{U} / \mathrm{L}$ on $28 \mathrm{~d}$ in $50 \%$ OMWW. Although to a lesser extent, MnP was also excreted during the first week of treatment and peaked during the second week for two out of the three treatments (more than $20 \mathrm{U} / \mathrm{L}$ and $\geq 10 \mathrm{U} / \mathrm{L}$ in OMWW $12.5 \%$ and $50 \%$, respectively). Manganese-independent peroxidase (MIP) was also generated toward the end of growth, but with a low activity in the lowest wastewater concentration ( $15 \mathrm{U} / \mathrm{L}$ in $12.5 \%$ OMWW).

In a study performed by Zerva et al. (2017), two ligninolytic white-root fungal strains, Pleurotus citrinopileatus LGAM 28684 and Irpex lacteus LGAM 238, were tested for their OMWW oxidative capacity. The treatment of OMWW $(25 \% \mathrm{v} / \mathrm{v})$ was investigated under several culture conditions, namely different $\mathrm{pH}$, agitation speed, as well as nitrogen-based supplements and their concentration. The selected parameters were $\mathrm{pH} 6$, agitation rate $150 \mathrm{rpm}, 30$ $\mathrm{g} / \mathrm{L}$ corn steep liquor as a nitrogen source for $P$. citrinopileatus and $20 \mathrm{~g} / \mathrm{L}$ diammonium tartrate for I. lacteus. Employing OMWW as substrate, the production of biotechnologically valuable enzymes such as Lacc $(1048.9 \pm 2.9$ $\mathrm{U} / \mathrm{L}$ for $P$. citrinopileatus and $57.4 \pm 2.2 \mathrm{U} / \mathrm{L}$ for $I$. lacteus $), \mathrm{MnP}(303.7 \pm 15.2$ $\mathrm{U} / \mathrm{L}$ for $P$. citrinopileatus and $100.2 \pm 5.0 \mathrm{U} / \mathrm{L}$ for I. lacteus $)$, and MIP $(735.0$ $\pm 4.27 \mathrm{U} / \mathrm{L}$ for $P$. citrinopileatus and $674.9 \pm 33.0 \mathrm{U} / \mathrm{L}$ for $I$. lacteus) was demonstrated with simultaneous effluent degradation and detoxification (above $90 \%$ color and phenols reduction within a $24 \mathrm{~d}$ cultivation period).
Other enzymes such as lipases and pectinases can also be obtained through OMWW fungal treatment. Cordova et al. (1999) obtained lipases for application in the dairy, pharmaceutical, detergent, and other industries from OMWW fermentation based on the (variable) amounts of remnant oil present in this residue. Although some filamentous fungi have the ability to synthesize lipase enzymes such as Aspergillus oryzae, Aspergillus niger. Geotrichum candidum, Penicillium citrinum, Rhizopus arrhizus and Rizhopus oryzae, and have been consequently recognized as lipolytic species (Crognale et al., 2006), D’Annibale et al. (2006) reported Candida cylindracea NRRL Y-17506 as a promising yeast with high potentials for lipase production from OMWW supplemented with $\mathrm{NH}_{4} \mathrm{Cl}$ and olive oil (optimal lipase activity of $9.23 \mathrm{U} / \mathrm{cm}^{3}$ ).

OMWW pretreated with precipitating agents and supplemented with a pectin-rich residue (sunflower by-product) was found to be a good medium for the production of pectolytic enzymes by the yeast strain Cryptococcus albidus var. albidus IMAT 473. The enzyme obtained was compared with commercially available preparations (Pectinex by Novo Enzymes, Pectinase by Fluka, and Ultrazym by Ciba-Geigy), and was shown to be an endopolygalacturonase with a large spectrum of activity on pectin with different degrees of methylation (Federici, 1985; Federici et al., 1988; Petruccioli et al., 1988).

\subsubsection{Polysaccharides}

Similar to the other agro-industrial residues, OMWW could be a strong potential source for the production of biomolecules with industrial applications, exopolysaccharides (EPSs) not being the exception. Although at present most of these EPSs come from plants and algae (with the exception of xanthan and curdlan), the use of inexpensive raw materials to produce EPSs by microorganisms represents a challenge since not only the properties of these compounds could be similar to or almost identical with those derived from vegetable biomass, but also because they could reduce production costs (Sutherland, 1998).

EPSs are bio-based extracellular and polymeric substances with diverse structural complexities and biological functions, and have extremely versatile applications. They can be used in the food, pharmaceuticals, cosmetics, and bioremediation fields (Liang and Wang, 2015).

Xanthan is one of the most commercially added-value microbial EPS. It is a polymer of repeated units of glucose, mannose, and glucuronic acid at a 2:2:1 ratio. Currently, xanthan is widely used in cosmetic formulations as an emulsion stabilizer or as a food supplement and a rheology modifier; it is also a thickening agent in salad dressings (Petri, 2015). The first xanthan production from OMWW was described by López and Ramos-Cormenzana (1996). Employing a Xanthomonas campestris NRRL B1459-S4L41 strain, they demonstrated that the maximum xanthan production of up to $4 \mathrm{~g} / \mathrm{L}$ could be achieved when the bacterium was grown in 30\% v/v OMWW solution. Moreover, EPS production was increased when phosphate-buffer was supplemented to the medium, reaching a final xanthan concentration of $6.3 \mathrm{~g} / \mathrm{L}$. In a different experiment, four X. campestris strains were tested in different $\% \mathrm{v} / \mathrm{v}$ OMWW solutions. Highest xanthan concentrations were obtained when using 30\% v/v OMWW, with values ranging from 3.48 to $7.01 \mathrm{~g} / \mathrm{L}$ (López et al., 2001).

Other EPS-producing bacteria capable of growing in OMWW have also been reported. Aguilera et al. (2001) reported the synthesis of a heteropolysaccharide consisting of fucose, xylose, rhamnose, arabinose, mannose, galactose, and glucose units, by using Paenibacillus jamilae sp. and raw OMWW. Ruiz-Bravo et al. (2001) also reported the production of an EPS when $P$. jamilae CP-7 was grown on an $80 \%$ v/v OMWW-based medium, and Morillo et al. (2007) obtained an EPS composed of glucose, galactose, mannose, arabinose, rhamnose, hexosamines, and uronic acid, also from diluted $80 \% \mathrm{v} / \mathrm{v}$ OMWW by using $P$. jamilae CECT 5266. Aguilera et al. (2008) isolated 60 different strains of the genus Paenibacillus from compost irrigated with OMWW. The screening-trials, performed in shake flasks, showed that only ten strains were able to synthesize EPSs. Out of those, $P$. jamilae CP-38 was the strain with the best yield $(4.2 \mathrm{~g} / \mathrm{L}$ of EPS in $80 \% \mathrm{v} / \mathrm{v}$ OMWW), within $48 \mathrm{~h}$. Subsequent experiments using a $2 \mathrm{~L}$ bioreactor demonstrated an increase in the amoun of the EPS produced, reaching $5.2 \mathrm{~g} / \mathrm{L}$ at the end of $72 \mathrm{~h}$ of fermentation.

Fungi are also known for their ability to synthesize EPSs. RamosCormenzana et al. (1995) reported the growth and pullulan synthesis by 
Table 2.

Main enzymes produced during the biological treatment of OMWW by ligninolytic fungi.

\begin{tabular}{|c|c|c|c|c|c|c|c|}
\hline \multirow{2}{*}{ Microorganism } & \multirow{2}{*}{ Treatment conditions } & \multicolumn{3}{|c|}{ Reduction (\%) } & \multirow{2}{*}{ Time } & \multirow{2}{*}{ Enzymes } & \multirow{2}{*}{ References } \\
\hline & & Color & Phenolic & COD/TOC & & & \\
\hline Lentinus edodes (SC-495) & $\begin{array}{l}\text { Five-fold diluted OMWW in medium } \\
\text { containing glucose } 5 \mathrm{~g} / \mathrm{L} \text { and yeast extract } 2 \\
\text { g/L. Trials were performed in shaking- } \\
\text { flasks with } 5 \%(\mathrm{v} / \mathrm{v}) \text { inoculums. }\end{array}$ & 90 & 66 & 85 & $12 \mathrm{~d}$ & $\begin{array}{l}\text { Phenoloxidases } \\
\mathrm{MnP}\end{array}$ & Vinciguerra et al. (1995) \\
\hline Pleurotus ostreatus & $\begin{array}{l}10 \%(\mathrm{v} / \mathrm{v}) \text { water-diluted OMWW was } \\
\text { incubated with the fungus previously } \\
\text { adapted in PDYm medium (potato dextrose } \\
\text { broth, yeast extract, and maltose) } \\
\text { containing up to } 20 \% \text { OMWW. }\end{array}$ & n.a. & 90 & n.a. & $100 \mathrm{~h}$ & Phenoloxidases & Martirani et al. (1996) \\
\hline $\begin{array}{l}\text { Abortiporus biennis } \\
\text { (CCBAS 521) }\end{array}$ & \multirow{4}{*}{$\begin{array}{l}\text { Prior to biological treatments, OMWW was } \\
50 \%(\mathrm{v} / \mathrm{v}) \text { water-diluted and the } \mathrm{pH} \text { was } \\
\text { adjusted to } 6.0 \text { with } \mathrm{H}_{3} \mathrm{PO}_{4} \text {. The white-rot } \\
\text { fungi were first cultivated on } 50 \% \text { water- } \\
\text { diluted OMWW plus agar } 1.6 \%(\mathrm{w} / \mathrm{v}) \text {. }\end{array}$} & 9.10 & 54.5 & \multirow{4}{*}{ n.a. } & \multirow{4}{*}{$30 \mathrm{~d}$} & $\mathrm{Jacc}$ & \multirow{4}{*}{ Aggelis et al. (2002) } \\
\hline $\begin{array}{l}\text { Pleurotus ostreatus } \\
\text { (CCBAS } 472 \text { ) }\end{array}$ & & 48.9 & 51.5 & & & MIP & \\
\hline $\begin{array}{l}\text { Panellus stipticus } \\
\text { (CCBAS } 450)\end{array}$ & & 8.40 & 42.2 & & & $\begin{array}{l}\text { MnP (only } \\
\text { observed in } \\
\text { P. ostreatus and } \\
\text { A. biennis) }\end{array}$ & \\
\hline $\begin{array}{l}\text { Dichomitus squalens } \\
\text { (CCBAS 751) }\end{array}$ & & n.a. & 36.4 & & & & \\
\hline Pleurotus flavido-alba & $\begin{array}{l}\text { Bioreactor was filled with basal medium } \\
\text { plus veratryl alcohol }(0.43 \mathrm{~g} / \mathrm{L}) \text {, Tween } 20 \\
(0.5 \mathrm{~g} / \mathrm{L}) \text {, and supplemented with } \mathrm{Mn}(\mathrm{II}) \text {. } \\
\text { After } 5 \mathrm{~d} \text { of fermentation, concentrated and } \\
\text { sterilized OMWW was added to the } \\
\text { bioreactor. }\end{array}$ & 70 & 51 & n.a. & $14 \mathrm{~d}$ & $\begin{array}{l}\mathrm{MnP} \\
\mathrm{Lacc}\end{array}$ & Blánquez et al. (2002) \\
\hline \multirow{3}{*}{ Pleurotus ostreatus } & Undiluted OMWW thermally processed. & \multirow{3}{*}{ n.a. } & 65 & 9 & $21 \mathrm{~d}$ & \multirow{3}{*}{$\begin{array}{l}\mathrm{MnP} \\
\mathrm{LiP} \\
\mathrm{Lacc}\end{array}$} & \multirow{3}{*}{ Fountoulakis et al. (2002) } \\
\hline & $\begin{array}{l}\left.\text { OMWW thermally processed (at } 100{ }^{\circ} \mathrm{C}\right) \\
\text { and water diluted at } 50 \%(\mathrm{v} / \mathrm{v}) \text {. }\end{array}$ & & 67 & 12 & $19 \mathrm{~d}$ & & \\
\hline & $\begin{array}{l}50 \%(\mathrm{v} / \mathrm{v}) \text { water-diluted and sterilized } \\
\left(120^{\circ} \mathrm{C}, 1 \mathrm{~atm}\right) \mathrm{OMWW} \text {. }\end{array}$ & & 78 & 10 & $21 \mathrm{~d}$ & & \\
\hline Pleurotus spp. LGAM P105 & \multirow{3}{*}{$\begin{array}{l}\text { Media containing } 75 \% \text { OMWW and } 25 \% \\
\text { distilled water, without any addition of } \\
\text { nutrients or pretreatment. }\end{array}$} & \multirow{3}{*}{ n.a. } & 69 & & \multirow{3}{*}{$24 \mathrm{~d}$} & \multirow{3}{*}{ Lacc } & \multirow{3}{*}{ Tsioulpas et al. (2002) } \\
\hline $\begin{array}{l}\text { Pleurotus spp. LGAM P112 } \\
\text { Pleurotus spp. LGAM P113 }\end{array}$ & & & 71 & n.a. & & & \\
\hline Pleurotus spp. LGAM P116 & & & 73 & & & & \\
\hline Pleurotus sajor-cajú & \multirow{5}{*}{$\begin{array}{l}\text { Discoloration and COD removal from } \\
\text { crude water-diluted OMWW at } 50 \mathrm{~g} / \mathrm{L} \\
\text { (MWL50) and } 75 \mathrm{~g} / \mathrm{L} \text { COD (MWL75), } \\
\text { without any additional carbon sources. }\end{array}$} & $\begin{array}{l}\text { MWL50: } 72.1 \\
\text { MWL75: } 54.5\end{array}$ & n.a. & $\begin{array}{l}49.9 \\
36.7\end{array}$ & \multirow{5}{*}{$20 \mathrm{~d}$} & $\begin{array}{l}\mathrm{MnP} \\
\mathrm{Lacc}\end{array}$ & \multirow{5}{*}{ Jaouani et al. (2003) } \\
\hline Lentinus (Lentinula) tigrinus & & $\begin{array}{l}\text { MWL50: } 49.6 \\
\text { MWL75: } 24.1\end{array}$ & n.a. & $\begin{array}{l}39.2 \\
24.1\end{array}$ & & $\begin{array}{l}\mathrm{MnP} \\
\mathrm{Lacc}\end{array}$ & \\
\hline Coriolopsis polyzona & & $\begin{array}{l}\text { MWL50: } 74.6 \\
\text { MWL75: } 33.0\end{array}$ & n.a. & 22.5 & & $\begin{array}{l}\mathrm{MnP} \\
\mathrm{Lacc} \\
\mathrm{LiP}\end{array}$ & \\
\hline \multirow{2}{*}{ Pycnoporus coccineus } & & MWL50: 57.6 & \multirow{2}{*}{ n.a. } & 47.1 & & $\mathrm{MnP}$ & \\
\hline & & MWL75: 36.7 & & 25.1 & & Lacc & \\
\hline
\end{tabular}

COD : Chemical Oxygen Demand; TOC :Total Organic Carbon

Lacc : Lacasse; LiP : Lignin Peroxidase; MnP : Manganese (Mn) Peroxidase; MIP : Mn-independent Peroxidase n.a. : no available

Aureobasidium pullulans in $70 \% \mathrm{v} / \mathrm{v}$ OMWW solution. Botryosphaeria rhodina was investigated in different types of undiluted OMWW (i.e., $\mathrm{OMWW}_{1}$, obtained from a traditional three-phase extraction system; $\mathrm{OMWW}_{2}$ and $\mathrm{OMWW}_{3}$, obtained from three-phase systems with low water consumption and $\mathrm{OMWW}_{4}$, obtained from a press extraction system) to produce $\beta$-glucan. Remarkable quantities of EPS were produced, although maximal $\beta$-glucan production was obtained at $120 \mathrm{~h}$ in $\mathrm{OMWW}_{4}\left(17.2 \mathrm{~g} / \mathrm{dm}^{3}\right)$ whose highest concentrations of COD and total sugars markedly promoted EPS production (Crognale et al., 2003). Later, the same researchers evaluated the technical feasibility of scaling up the EPS production process in a $3 \mathrm{dm}^{3}$ bench-top reactor by $B$. rhodina cultured in $\mathrm{OMWW}_{4}$. Maximum production of $\beta$ glucan was slightly lower $\left(16.8 \mathrm{~g} / \mathrm{dm}^{3}\right)$ than the one obtained in shaking cultures, but a peak was achieved $24 \mathrm{~h}$ earlier (Crognale et al., 2006).

\subsubsection{Biosurfactants}

Biosurfactants are surface-active biological derivatives that, although produced mainly through fermentation employing microorganisms, are not directly associated with their growth, so that they are considered as secondary metabolites (Kourmentza et al., 2017). These compounds are 
stable at extreme $\mathrm{pH}$, salinity, and temperature conditions, and can be employed in novel applications such soil remediation, recovery of heavy metals, food or medicine (Shekhar et al., 2015).

Biosurfactants, amphipathic agents with hydrophilic "heads" and hydrophobic "tails", are characterized by their ability to alleviate the surface tension of water or interfacial tension between two opposite phases, aqueous and hydrophobic. Due to residual oils and the presence of polysaccharides (Aguilera et al., 2008; Dermeche, 2013), OMWW constitutes a suitable carbon source for the production of biosurfactants in the form of rhamnolipids (glycolipid biosurfactants) or surfactins (lipopeptide biosurfactants). Mercadé et al. (1993) were the first to investigate the synthesis of rhamnolipids using Pseudomonas sp. JAMM and OMWW as the sole carbon source. After $72 \mathrm{~h}$ of incubation, rhamnolipid conversion yield reached $0.058 \mathrm{~g} / \mathrm{g}_{\mathrm{OMww}}$, coinciding at the same time with $50 \%$ COD reduction and $55 \%$ removal of the total phenolic content in OMWW. Nevertheless, maximum rhamnolipid production was estimated at $14 \mathrm{~g} / \mathrm{Kg}$ омww, after $150 \mathrm{~h}$ of fermentation. Two decades later, Colak and Kahraman (2013) cultured a wild-type strain and a recombinant strain of $P$. aeruginosa ATCC 10145 in OMWW for rhamnolipid production. With both wild-type and recombinant strains, the maximum rhamnolipid yield reached as high as $0.4 \mathrm{~g} / \mathrm{L}$ after a growth period at $37^{\circ} \mathrm{C}$, at $100 \mathrm{rpm}$ and $72 \mathrm{~h}$. Ramírez et al. (2015) looked into rhamnolipid and surfactin synthesis with $P$. aeruginosa and B. subtilis strains, using $2-10 \% \mathrm{v} / \mathrm{v}$ OMWW solutions. The results obtained showed that surfactin reached production levels of $3.12 \mathrm{mg} / \mathrm{L}$ for $B$. subtilis in $2 \%$ OMWW that then dropped to $0.57 \mathrm{mg} / \mathrm{L}$ at the most often used concentrated OMWW solution $(10 \% \mathrm{v} / \mathrm{v})$. In contrast, $P$. aeruginosa reached rhamnolipid values from 8.78 in $2 \%$ OMWW to $191.46 \mathrm{mg} / \mathrm{L}$ when the highest OMWW concentration was used.

\subsubsection{Bioactive compounds}

In nature, phenolics appear as single molecules (acid phenols), or highly polymerized compounds such as tannins. Nevertheless, the most common phenolics are those conjugated with mono-, di-, or oligosaccharides sugars, organic acids, and lipids, or even with alternative phenols coupled to hydroxyl radicals or, less frequently, to aromatic carbon atoms (Bravo, 1998; Shahidi, 2003).

OMWW has been widely investigated as a source of bioactive compounds, and the antioxidant activity of phenolics extracted from olive by-products has also been reported (Salido et al., 2015; Gullón et al., 2018). Phenols are present in OMWW mainly as colored pigments; their concentrations vary according to their chemical polarity, olive variety, and way of cultivation, as well as oil extraction methods and treatments applied to olive mill wastes (Dourou et al., 2016). Moreover, other factors including ripeness of the fruit, climate, agronomic conditions, storage conditions prior to oil extraction, and processing techniques could also have significant quantitative and qualitative impacts on OMWW bioactive compounds (Allouche et al., 2004; Obied et al., 2005).

Although the phenolic content may differs in OMWW, the main compounds described in the literature are phenolic acids, secoiridoids, and flavonoids (Lafka et al., 2011). Bianco et al. (2003) identified 20 prevalent classes of bioactive compounds in OMWW using HPLC-MS/MS, including phenylalcohols, phenols acids, secoiridoid derivatives, flavonoids (luteolin, luteolin7-glucoside), and lignans. Visioli et al. (2002) reported oleuropein (an ester of elenolic acid) and hydroxytyrosol as primary bioactive compounds in OMWW. Other phenols also detected in OMWW are M4-methylcatechol, 4hydroxybenzoic acid, protocatechuic acid, vanillic acid, 3,4dihydroxyphenylglycol, homovanillic alcohol, 4-hydroxy-3,5dimethoxybenzoic acid, 3,4-dihydroxyphenylacetic acid, 2-(4-hydroxy-3methoxy) phenylethanol, and 2-(3,4- dihydroxyphenyl)-1,2-ethandiol (Capasso et al., 1992; Aramendia et al., 1996; Della Greca et al., 2001). All these compounds showed anti-hypertensive, anti-inflammatory, hypoglycaemic, and hypocholesterolemic properties, and in some cases, exhibited antimicrobial properties against certain bacteria, fungi, and mycoplasma (Ghanbari et al., 2012).

Bioconversion has been used to recover bioactive compounds from olive byproducts. Khoufi et al. (2011) showed that an enzymatic extract from Aspergillus niger, mainly comprising $\beta$-glucosidase and esterase, had the potential to produce free simple phenolic compounds. The hydrolytic activity of the preparation was assayed upon three substrates: raw OMWW, the phenolic fraction extracted from OMWW with ethyl acetate, and its corresponding spent fraction. Huge quantities of bioactive phenolics (especially hydroxytyrosol, HT) were released from the spent fraction $(0.75$ $\mathrm{g} / \mathrm{L})$ and from raw OMWW (0.56 g/L) after enzymatic treatment, with promising applications in food processing and pharmaceutical industries. Hamza et al. (2012) performed a similar study, treating OMWW enzymatically with $\beta$-glucosidase-rich Aspergillus niger, Trichoderma atroviride, and Trametes trogii culture broths in order to release compounds with antioxidants properties. In the first two cases, the amount of HT released increased from $0.05 \mathrm{~g} / \mathrm{L}$ up to $1.1 \mathrm{~g} / \mathrm{L}$ and $0.50 \mathrm{~g} / \mathrm{L}$, respectively, while $T$. trogii broth culture led to the oxidation of the phenolics instead of their recovery because of the high Lacc enzyme titers recorded for this fungus.

Other methods based on the use of biofilters have also been studied for the recovery of polyphenols from OMWW. Ena et al. (2012) employed adsorbing vegetable and mineral matrices, Azolla and granular activated carbon, respectively, with an important capacity for both adsorption and desorption of HT from OMWW. The two matrices showed high antioxidant capacity and antiradical activity.

Overall, biorecovery of OMWW phenolic compounds could not only provide economic advantages, but also could make this wastewater less harmful and easier to treat, thus resulting in OMWW sustainable management (Federici et al., 2009).

\subsection{Uses of $O M W W$ in agriculture}

\subsubsection{Co-composting}

The treatment of highly organic OMWW and its use as fertilizer could be regarded among the most suitable and sustainable alternatives in order to manage this waste. This could be ascribed to the fact that through such an application, the nutrients taken up by olive trees cultivation could be returned to croplands (Arvanitoyannis and Kassaveti, 2007).

Composting is defined as a degradation process of solid organic wastes mediated by microorganisms. Such biological decomposition can occur at either aerobic (Makan et al., 2014) or anaerobic (Minale and Worku, 2014) conditions, with the former being more common. During composting, organic matter is transformed through the enzymatic activities of specialized microbial populations, producing a stable and humus-rich complex mixture (Cooperband, 2002; Federici et al., 2011).

During the composting process, factors such as substrates composition, initial $\mathrm{C} / \mathrm{N}$ ratio, temperature, $\mathrm{pH}$, aeration, porosity, and moisture content must be adjusted in order to provide an optimum environment for the degradation of organic loads, and the humification process. As a liquid, OMWW could not be directly composted but has been employed to produce high-quality composts in combination with saw dust, domestic sewage sludge, manures, and cereal straws among other solid substrates in a process called "co-composting" (Akratos et al., 2017).

Compost is regarded advantageous as a fertilizer agent since it: (i) improves soil water capacity and aggregates stability; (ii) boosts cation exchange; (c) enhances microbial activity, and (d) increases the degradation of pesticides and other synthetic organic substances (Cerda et al., 2018). Moreover, the composted material obtained has favorable consequences for both soil and water microbial abundance and diversity (Doan et al., 2014), avoiding drawbacks often observed in direct applications such as phytotoxicity, leaching of nutrients, and inhibition of soil microflora (Felipo, 1996).

Co-composting of OMWW depends on the proper adjustment of $\mathrm{pH}$, temperature, moisture, oxygenation, and nutrients as well as on the adequate development of the microbial populations (Arvanitoyannis and Kassaveti, 2007). Chang et al. (2006) reported that the optimal conditions for an ideal OMWW co-composting process were a starting $\mathrm{C} / \mathrm{N}$ ratio of 20 to 40 , a moisture content of around $50 \%-60 \%$, an adequate oxygen supply, small particle size, and enough interstitial space through which air could flow.

Controlling microbial populations is essential to understand the composting process of OMWW and to make it successful. However, there are still only a few reports in the literature on this topic. Abid et al. (2007) published a study focused on the analysis of the microbial communities during the composting of an OMWW sludge (obtained by electro-Fenton oxidation of OMWW) in a bench-scale reactor. The dynamics of microbia diversity was followed through a respirometric test and by means of both 
cultivation-dependent and cultivation-independent techniques (PCR-singlestrand conformation polymorphism; SSCP). During the 7-24 d (the period of high respiration rates), the direct cultivation method showed that thermophilic bacteria and actinomycetes prevailed over eumycetes; however, the PCRSSCP method showed a higher diversity in the bacterial community than in the eukaryotic ones during the $60 \mathrm{~d}$ of the process. Vivas et al. (2009) assessed the changes in the microbial community during composting and vermicomposting (characterized by the addition of earthworms) of an olive-mill waste. They used the real-time PCR assay targeting $16 \mathrm{~S}$ rRNA genes and the denaturing gradient gel electrophoresis profiling-sequence analysis of PCR-amplified 16S rRNA fragments (PCR-DGGE) in order to determine functional diversity, bacterial number, and bacterial community structure. The results of this study demonstrated that Proteobacteria was the most abundant bacterial phylum in both composting and vermicomposting. Additionally, the authors demonstrated that olive mill waste composting and vermicomposting modified the original microbial communities of the olive waste in different ways. Whereas the most representative bacteria in the mature compost (Actinobacteria and Gammaproteobacteria) were more abundant in olive waste vermicomposting, bacterial phylogenetic groups typical of non-cured compost (Alphaproteobacteria and Bacteriodetes) were clearly determined in olive waste composting.

Vermicomposting was more effective in activating the microbial metabolism and bacterial diversity of the olive mill toxic waste, probably because Eisenia foetida (the earthworms used as a starting inoculum) has a unique indigenous gut-associated microflora which could contribute to and modify the original microbial community (Toyota and Kimura, 2000). In a recent work, El Moussaoui et al. (2017) studied the behavior of microbial biomass in a conventional activated sludge used in the treatment of OMWW. Microbial growth and biomass activity, measured through specific oxygen uptake rate (SOUR), were determined continuously for $70 \mathrm{~d}$. Moreover, the dynamics of aerobic microbial communities of the activated sludge was also assessed using the following as culture media: Plate Count Agar to enumerate aerobic revivable bacteria at $22^{\circ} \mathrm{C}(\mathrm{ARB} 22)$ and at $37^{\circ} \mathrm{C}$ (ARB37), Cetrimide Agar to isolate Pseudomonas sp. followed by identification in a special medium King A, Sabouraud Agar Medium for mold and yeast counts, and finally Potato Dextrose Agar supplemented with antibacterial for the cultivation of total fungi. The results revealed the biological treatment of OMWW with an efficient activated sludge system. It was also reported that the microbial biomass showed a good response to the increase in OMWW rate through good growth, a stable physiological state, and an adequate settling capacity of the flocs. Aerobic bacteria ARB22, ARB37, Pseudomonas sp., yeast, and fungi concentrations increased significantly from an initial $30 \%$ OMWW concentration until the end of the assay.

A stable organic matter content indicates if the compost has a high degree of stability or maturity, is free of phytotoxic elements and plant or animal pathogens, and thus, if it is suitable to be safely applied to soil (Chowdhury et al., 2013). Whereas maturity is associated with phytotoxicity, stability is often related to the microbial metabolism of compost (Iannotti et al., 1993). In turn, stability depends on the relative stability of the composting substrates and on the effect of other physicochemical characteristics of the compost on the growth and development of the plants. This indicates that maturity does not include only a single property, so that it is better evaluated through the measurement of two or more compost parameters. According to the California Compost Quality Council, criteria and parameters for checking compost maturity are based on different physical, chemical, and biological features (CCQC, 2001).

The germination index (GI), a fundamental parameter used to evaluate compost phytotoxicity, is one of the most important indices of maturity. When GI values are close to zero or below $80 \%$ in the initial activation stage, they indicate very high phytotoxicity of the composting mixture (Lasaridi et al., 2006). Principally, low GI values could be attributed to the fact that at the starting stage, substrates have high concentrations of water-soluble organic substances, toxic constituents like alcohols, organic fatty acids and phenolic compounds, elevated $\mathrm{C} / \mathrm{N}$ ratios due to the presence of ammonia and other toxic nitrogen-based products, as well as high heavy metals and mineral salt contents (Said-Pullicino and Gigliotti, 2007). After the maturation phase, the GI increases to values ranging from a minimum of $66 \%$ (Gigliotti et al., 2012) to a maximum of $201 \%$ (Zorpas and Costa, 2010), thus surpassing the threshold limit of $80 \%$ that determines the phytotoxicity of the compost (Zucconi et al., 1985). A relatively high GI recorded at the end of the composting indicates that
OMWW could be converted into a high-value soil amendment. Makni et al (2010) composted OMWW and obtained final GI values above $80 \%$, so that the final compost could be characterized as mature or very mature. The effectiveness of OMWW composting as a recycling technology in agriculture depends mostly on the quality of the compost; consequently, the characterization of the process plus the evaluation of the quality of the mature composted material are crucial (Cayuela et al., 2008a and b).

\subsubsection{Fungal biomass and edible mushrooms}

OMWW has long been used in the preparation of production media for the development of certain microorganisms with the aim to obtain potentially edible microbial biomass. Edible fungi, especially Pleurotus, Lentinula, and Agaricus species, were able to grow using olive mill wastes and wastewater as nutrient sources, by applying different strategies (Altieri et al., 2009; Koutrotsios et al., 2016). Kalmis et al. (2008) cultured the edible mushroom Pleurotus ostreatus on wheat straw substrate mixture with tap water and increasing concentrations of OMWW in order to investigate the feasibility of using OMWW as an alternative wetting agent and as an eco-friendly solution for the commercial production of mushroom. With a $25 \%$ OMWW (v/v) concentration, the experimental results showed positive effects on mushroom growth. Increasing volumes of OMWW showed negative effects, including lower bio-efficiency and deformation of fruit body shape. Lakhtar et al. (2010) screened sixteen strains of L. edodes but pre-selected only four of them (Le118, Le119, Le121, Le122) due to the higher biomass yields obtained when grown in the presence of $20 \%(\mathrm{v} / \mathrm{v})$ OMWW. Laconi et al. (2007) implemented a combined chemical-biological process (alkaline oxidative treatment to decrease polyphenols content of OMWW linked to a fungal fermentation) in order to obtain intense degradation of pollutants in OMWW coupled to the production of high-rich microbial biomass (mixture of edible fungi genus Pleurotus together with the yeasts $S$. cerevisiae, Kluyveromyces lactis and the species of filamentous fungi Oidodendron spp. and Penicillum spp.), which could be used as an animal feed additive. Up to $150-160 \mathrm{~g}$ of wet biomass with a protein content of about $13 \mathrm{~g}$ percent and $6 \mathrm{~g}$ percent of raw fiber were obtained per liter of treated OMWW.

In a recent study, Koutrotsios et al. (2016) evaluated the suitability of water diluted-OMWW $(12.5 \%, 25 \%$, and $50 \% \mathrm{v} / \mathrm{v})$ as a substrate for the production of $H$. erinaceus biomass. The $H$. erinaceus most abundant mycelium was obtained in 50\% OMWW, achieving $154.80 \pm 8.45 \mathrm{mg} / 100$ $\mathrm{mL}$.

Additionally, $P$. ostreatus presented satisfactory growth and reduced the phenolic content of sterilized OMWW in bioreactor cultures. However, high OMWW dilutions and/or additional treatment were still needed before the treated OMWW could be discharged into the environment, e.g., as water for irrigation (Aggelis et al., 2003). The biological evaluation of the treated OMWW as water for irrigation of plants growing in pots did not significantly affect the uptake of various nutrients, but plant yields were decreased, probably due to the high OMWW salinity (Aggelis et al., 2003).

\subsection{Another use of OMWW: fiber restoration for animal feed and food production}

The increasing fiber consumption trend has led to the development of a large potential market for fiber-enriched food products, ingredients, and gelling materials. Olive mill by-products contain olive cell wall polysaccharides debris and have been proposed as a source of polymers such as pectins, hemicelluloses, cellulose, lignin, as well as other products like gelling agents and fat replacements (Galanakis, 2010). Dietary fiber is defined as the traces of edible plant cells and consists of all the above substances plus other associated ones that are resistant to digestion by human enzymes (García et al., 2007). Although all these polysaccharides are present in olive mill wastes, the co-presence of phenolics and other organic matters hinders their extraction and purification and demands costly equipment, processes, and chemicals. OMWW and olive pomace are rich in pectic materials but they could not be transformed into an exploitable source of gelling agents because of their rich phenols contents (Cardoso et al., 2002). In this sense, efforts have been made to optimize the functiona properties of these pectic polysaccharides. In a recent research, selective lignin-degrading fungi and solid-state fermentation were used in an effort 
to improve the nutritional properties of an olive mill residue mixed with other feedstuffs (wheat bran, wheat middlings, barley grains, crimson clover, wheat flour shorts, and field beans) by using the macrofungi $P$. ostreatus and Pleurotus pulmonarius. Between 50\% and 90\% of the phenolic content was removed from the waste and its crude protein content was increased by $7-29 \%$ after 6 weeks (Brozzoli et al., 2010). Nevertheless, fiber production for either animal feed or food with a commercial interest using olive by-products as cheap and abundant sources seems feasible and competitive within the near future if the cost of treatments to eliminate their phenolic contents could be decreased (Federici et al., 2009; Dermeche, 2013).

\section{Concluding remarks and future prospects}

Olive oil represents one of the most important agricultural commodities. However, olive oil manufacturing leads to severe environmental degradation when OMWW is produced, discarded, and its management is not adequate. No individual treatment technology has proven suitable enough to be adopted by an olive oil-producing factory. Currently, olive processing-derivate wastes are either impounded in storage lagoons or discharged into receiving media, but an advisable treatment requires a multifactorial approach, combining a biological step that might integrate more than one type of bio-treatment with innovative process engineering to handle residues and derived compounds.

In accordance with the biorefinery concept, all sustainability features including economic, environmental, and social elements with an emphasis on the production of highly value-added compounds should be taken into account. In better words, this concept requires the appraisal of the whole biomass in terms of carbon and energy, based on a zero-waste notion

In light of the above, the future perspectives of the olive oil industry should be based on a biorefinery framework through which the possibility of using various waste streams including OMWW as renewable raw materials to generate high value-added products be explored. To achieve that, different biotechnological production processes including combined and/or sequential treatment schemes should be developed and implemented. The various high value products generated through such platforms ranging from bulk fertilizers and other soil amendment products to more specialized ones such as antioxidants, catalyzers, biofuels and biochemicals could significantly enhance the economic viability of the whole industry while simultaneously reduce its footprints. On the other hand, this would constitute a viable and safe solution for the environmental problems associated these waste streams.

\section{Acknowledgments}

This work was supported by ANPCyT through the projects PICT 20132016, PICT 2884-2014, PICT 3639-2015, Estación Experimental Agroindustrial Obispo Colombres (EEAOC), Consejo Nacional de Investigaciones Científicas y Técnicas (CONICET PUE 012/2016), and Consejo de Investigaciones de la Universidad Nacional de Tucumán (CIUNT).

\section{References}

[1] Abid, N., Chamkha, M., Godon, J.J., Sayadi, S., 2007. Involvement of microbial populations during the composting of olive mill wastewater sludge. Environ. Technol. 28(7), 751-760.

[2] Aggelis, G., Ehaliotis, C., Nerud, F., Stoychev, I., Lyberatos, G., Zervakis, G., 2002. Evaluation of white-rot fungi for detoxification and decolorization of effluents from the green olive debittering process. Appl. Microbiol. Biotechnol. 59(25-3), 353-360

[3] Aggelis, G., Iconomou, D., Christou, M., Bokas, D., Kotzailias, S., Christou, G., Tsagou, V., Papanikolaou, S., 2003. Phenolic removal in a model olive oil mill wastewater using Pleurotus ostreatus in bioreactor cultures and biological evaluation of the process. Water Res. 37(16), 3897-3904

[4] Aggoun, M., Arhab, R., Cornu, A., Portelli, J., Barkat, M., Graulet, B., 2016. Olive mill wastewater microconstituents composition according to olive variety and extraction process. Food Chem. 209, 72-80.

[5] Aguilera, M., Monteoliva-Sanchez, M., Suarez, A., Guerra, V., Lizama, C., Bennasar, A., Ramos-Cormenzana, A., 2001. Paenibacillus jamilae sp. nov., an exopolysaccharide-producing bacterium able to grow in olive-mill wastewater. Int. J. Syst. Evol. Microbiol. 51(5), 1687-1692.
[6] Aguilera, M., Quesada, M.T., Guerra del Aguila, V., Morillo, J.A. Rivadeneyra, M.A., Ramos-Cormenzana, A., 2008 Characterisation of Paenibacillus jamilae strains that produce exopolysaccharide during growth on and detoxification of olive mill wastewaters. Bioresour. Technol. 99(31), 5640-5644.

[7] Akratos, C.S., Tekerlekopoulou, A.G., Vasiliadou, I.A., Vayenas, D.V., 2017. Chapter 8- Cocomposting of olive mill waste for the production of soil amendments, in: Galanakis, C.M. (Ed.), Olive Mill Waste. Academic Press, Cambridge, MA, USA, pp. 161-182.

[8] Allouche, N., Fki, I., Sayadi, S., 2004. Toward a high yield recovery of antioxidants and purified hydroxytyrosol from olive mil wastewaters. J. Agric. Food Chem. 52(2), 267-273.

[9] Altieri, R., Esposito, A., Parati, F., Lobianco, A., Pepi, M., 2009 Performance of olive mill solid waste as a constituent of the substrate in commercial cultivation of Agaricus bisporus. Int Biodeterior. Biodegrad. 63(8), 993-997.

[10] Ammar, E., Ben Rouina, B., 1999. Potencial horticultura utilization of olive oil processing waste water. Acta Hortic. 474 741-744.

[11] Aparicio, R., Harwood, J., 2013. Handbook of olive oil: Analysis and Properties, second ed. Springer, New York

[12] Aramendia, M.A., Borau, V., Garcia, I., Jimenez, C., Lafont, F. Marinas, J.M., Urbano, F.J., 1996. Qualitative and quantitative analices of phenolic compounds by high performance liquid chromatography and detection with atmospheric pressure chemical ionization mass spectrometry. Rapid Commun. Mass Spectrom. 10, $1585-1590$.

[13] Arvanitoyannis, I.S., Kassaveti, A., 2007. Current and potential uses of composted olive oil waste. Int. J. Food Sci. Technol. 42 281-295

[14] Aviani, I., Raviv, M., Hadar, Y., Saadi, I., Dag, A., Ben-Gal, A., Yermiyahu, U., Zipori, I., Laor, Y., 2012. Effects of harvest date, irrigation level, cultivar type and fruit water content on olive mill wastewater generated by a laboratory scale 'Abencor' milling system. Bioresour. Technol. 107, 87-96.

[15] Azbar, N., Bayram, A., Filibeli, A., Muezzino glu, A., Sengül, F. Özer, A., 2004. A review of wastes management options in olive oil production. Crit. Rev. Env. Sci. Technol. 34(3), 209-247.

[16] Azbar, N., Keskin, T., Yuruyen, A., 2008. Enhancement of biogas production from olive mill effluent (OME) by co-digestion. Biomass Bioenergy. 32(12), 1195-1201

[17] Bellou, S., Makri, A., Sarris, D., Michos, K., Rentoumi, P., Celik, A., Papanikolaou, S., Aggelis, G., 2014. The olive mill wastewater as substrate for single cell oil production by Zygomycetes. J. Biotechnol. 170, 50-59.

[18] Bianco, A., Buiarelli, F., Cartoni, G., Coccioli, F., Jasionowska, R. Margherita, P., 2003. Analysis by liquid chromatography-tandem mass spectrometry of biophenolic compounds in olives and vegetation waters, Part I. J. Separation Sci. 26(5), 409-416.

[19] Blánquez, P., Caminal, G., Sarra, M., Vicent, M.T., Gabarrell, X., 2002. Olive oil mill waste waters decoloration and detoxification in a bioreactor by the white rot fungus Phanerochaete flavido-alba. Biotechnol. Progr. 18(3), 660-662.

[20] Borja, R., Alba, J., Garrido, S.E., Martinez, L., Garcia, M.P., Incerti, C., Ramos-Cormenzana, A., 1995. Comparative study of anaerobic digestion of olive mill wastewater (OMW) and OMW previously fermented with Aspergillus terreus. Bioprocess Eng. 13(6), 317-322.

[21] Bravo, L., 1998. Polyphenols: chemistry, dietary sources, metabolism and nutritional significance. Nutr. Rev. 56(11), 317 333.

[22] Brozzoli, V., Bartoccib, S., Terramoccia, S., Contò, G., Federici, F., D’Annibale, A., Petruccioli, M., 2010. Stoned olive pomace fermentation with Pleurotus species and its evaluation as a possible animal feed. Enz. Microb. Technol. 46(3-4), 223-228.

[23] Capasso, R., Evidente, A., Scognamiglio, F., 1992. A simple thin layer chromatographic method to detect the main polyphenols occurring in olive oil vegetation waters. Phytochem. Anal. 3(6), $270-275$ 
[24] Cardoso, S.M., Silva, A.M.S., Coimbra, M.A., 2002. Structural characterisation of the olive pomace pectic polysaccharide arabinan side chains. Carbohydr. Res. 337(10), 917-924.

[25] Cayuela, M.L., Millner, P.D., Meyer, S.L., Roig, A., 2008. Potential of olive mill waste and compost as biobased pesticides against weeds, fungi, and nematodes. Sci. Total Environ. 399(1-3), 11-18.

[26] Cayuela, M.L., Mondini, C., Sánchez-Monedero, M.A., Roig, A., 2008. Chemical properties and hydrolytic enzyme activities for the characterisation of two-phase olive mill wastes composting. Bioresour. Technol. 99(10), 4255-4262

[27] CCQC, 2001. Compost Maturity Index. California Compost Quality Council.

[28] Cerda, A., Artola, A., Font, X., Barrena, R., Gea, T., Sánchez, A., 2018. Composting of food wastes: status and challenges. Bioresour. Technol. $248,57-67$

[29] Chang, J.I., Tsai, J.J., Wu, K.H., 2006. Thermophilic composting of food waste. Bioresour. Technol. 97(1), 116-122

[30] Cheng, C.Y., 2006. In: Restructing of water industry in portugal. Aquastress conference.

[31] Chowdhury, A.K.M.M.B., Akratos, C.S., Vayenas, D.V., Pavlou, S., 2013. Olive mill waste composting: a review. Int. Biodeterior. Biodegrad. 85, 108-119.

[32] Colak, A.K., Kahraman, H., 2013. The use of raw cheese whey and olive oil mill wastewater for rhamnolipid production by recombinant Pseudomonas aeruginosa. Environ. Exp. Biol. 11(3), 125-130.

[33] Cooperband, L., 2002. The Art and Science of Composting: A Resource for Farmers and Compost Producers. UW Center for Integrated Agricultural Systems, University of Wisconsin, Madison.

[34] Cordova, J., Nemmaoui, M., Ismaili-Alaoui, M., Morin, A., Roussos, S., Raimbault, M., Benjilali, B., 1999. Lipase production by solid-state fermentation of olive cake and sugarcane bagasse. J. Mol. Catal. B: Enzym. 5(1-4), 75-78.

[35] Crognale, S., D’Annibale, A., Federici, F., Fenice, M., Quaratino, D., Petruccioli, M., 2006. Olive oil mill wastewater valorisation by fungi. J. Chem. Technol. Biotechnol. 81(9), 1547-1555.

[36] Crognale, S., Federici, F., Petruccioli, M., 2003. $\beta$-Glucan production by Botryosphaeria rhodina on undiluted olive-mill wastewaters. Biotechnol. Lett. 25(23), 2013-2015.

[37] D’Annibale, A., Sermanni, G.G., Federici, F., Petruccioli, M., 2006. Olive mill wastewaters: a promising substrate for microbial lipase production. Bioresour. Technol. 97(15), 1828-1833.

[38] Danellakis, D., Ntaikou, I., Kornaros, M., Dailianis, S., 2011. Olive oil mill wastewater toxicity in the marine environment: Alterations of stress indices in tissues of mussel Mytilus galloprovincialis. Aquat. Toxicol. 101(2), 358-366.

[39] Dareioti, M.A., Dokianakis, S.N., Stamatelatou, K., Zafiri, C., Kornaros, M., 2010. Exploitation of olive mill wastewater and liquid cow manure for biogas production. Waste Manage. 30(10), 1841-1848.

[40] Della Greca, M., Previtera, L., Temussi, F., Zarrelli, A., 2004. Lowmolecular-weight components of olive oil mill waste-waters. Phytochem. Anal. 15(3), 184-188

[41] Dermeche, S., Nadour, M., Larroche, C., Moulti-Mati, F., Michaud, P. 2013. Olive mill wastes: biochemical characterizations and valorization strategies. Process Biochem. 48(10), 1532-1552.

[42] Dhouib, A., Ellouz, M., Aloui, F., Sayadi, S., 2006. Effect of bioaugmentation of activated sludge with white-rot fungi on olive mill wastewater detoxification. Lett. Appl. Microbiol. 42(4), 405-411.

[43] Di Giovacchino, L., Sestili, S., Di Vincenzo, D., 2002. Influence of olive processing on virgin olive quality. Eur. J. Lipid Sci. Technol. 104(9-10), 587-601.

[44] Directive on Urban Wastewater Treatment, 1991. The European Union.

[45] Doan, T.T., Bouvier, C., Bettarel, Y., Bouvier, T., Henry-des-Tureaux, T., Janeau, J.L., Lamballe, P., Van Nguyen, B., Jouquet, P., 2014. Influence of buffalo manure, compost, vermicompost and biochar amendments on bacterial and viral communities in soil and adjacent aquatic systems. Appl. Soil Ecol. 73, 78-86.

[46] Dourou, M., Kancelista, A., Juszczyk, P., Sarris, D., Bellou, S., Triantaphyllidou, I.E., Rywinska, A., Papanikolaou, S., Aggelis, G., 2016. Bioconversion of olive mill wastewater into high-added value products. J. Cleaner Prod. 139, 957-969.
[47] El Moussaoui, T., Jaouad, Y., Mandi, L., Marrot, B., Ouazzani, N. 2017. Biomass behaviour in a conventional activated sludge system treating olive mill wastewater. Environ. Technol. 39(2), 190-202.

[48] El-Abbassi, A., Kiai, H., Hafidi, A., 2012. Phenolic profile and antioxidant activities of olive mill wastewater. Food Chem. 132(1), 406-412.

[49] Ena, A., Pintucci, C., Carlozzi, P., 2010. Production of bioH2 by Rhodopseudomonas palustris (strain 6A) grown in pre-treated olive mill waste, under batch or semicontinuous regime. J. Biotechnol. (150), 180

[50] Ena, A., Pintucci, C., Carlozzi, P., 2012. The recovery of polyphenols from olive mill waste using two adsorbing vegetable matrices. J. Biotechnol. 157(4), 573-577.

[51] Eroglu, E., Eroglu, I., Gunduz, U., Yucel, M., 2009 Comparison of the physicochemical characteristics and photofermentative hydrogen production potential of wastewaters produced from different olive-oil mills in Western-Anatolia, Turkey. Biomass Bioenergy. 33(4), 706-711.

[52] Eroglu, E., Gunduz, U., Yucel, M., Eroglu, I., 2010. Photosynthetic bacterial growth and productivity under continuous illumination or diurnal cycles with olive mill wastewater as feedstock. Int. J. Hydrogen Energy. 35(11), 5293-5300

[53] Eroglu, E., Gunduz, U., Yucel, M., Eroglu, I., 2011. Effect of iron and molybdenum addition on photofermentative hydrogen production from olive mill wastewater. Int. J. Hydrogen Energy. 36(10), 5895-5903.

[54] Eroglu, E., Gunduz, U., Yucel, M., Turker, L., Eroglu, I., 2004 Photobiological hydrogen production by using olive mill wastewater as a sole substrate source. Int. J. Hydrogen Energy. 29(2), 163-171.

[55] Eroglu, E., Gunduz, U., Yucel, M., Turker, L., Eroglu, I., 2006. Biological hydrogen production from olive mill wastewater with two stage processes. Int. J. Hydrogen Energy. 31(11), 1527-1535.

[56] FAOSTAT, 2018. Food and Agriculture Organization of the United Nations.

[57] Faraloni, C., Ena, A., Pintucci, C., Torzillo, G., 2011. Enhanced hydrogen production by means of sulfur-deprived Chlamydomonas reinhardtii cultures grown in pretreated olive mill wastewater. Int J. Hydrogen Energy. 36(10), 5920-5931.

[58] Federici, E., Pepi, M., Esposito, A., Scargetta, S., Fidati, L. Gasperini, Cenci, G., Altieri, R., 2011. Two-phase olive mill waste composting: community dynamics and functional role of the resident microbiota. Bioresour. Technol. 102(23), 10965-10972.

[59] Federici, F., 1985. Production, purification and partial characterization of an endo-polygalacturonase from Cryptococcus albidus var. albidus. Antonie van Leeuwenhoek. 51(2), 139-150.

[60] Federici, F., Fava, F., Kalogerakis, N., Mantzavinos, D., 2009 Valorisation of agro-industrial by-products, effluents and waste: concept, opportunities and the case of olive mill wastewaters. J Chem. Technol. Biotechnol. 84(6), 895-900.

[61] Federici, F., Montedoro, G.F., Servili, M., Petruccioli, M., 1988 Pectic enzyme production by Cryptococcus albidus var. albidus on olive oil vegetation waters enriched with sunflower calathide meal Biol. Wastes. 25(4), 291-301.

[62] Felipo, M.T., 1996. Compost as a source of organic matter in Mediterranean soils, in: De Bertoldi, M., Sequi, P., Lemmes, B., Papi, T. (Eds.), The science of composting. Blackie Academic and Professional, Glasgow, pp. 403-412.

[63] Fenice, M., Sermanni, G.G., Federici, F., D’Annibale, A., 2003 Submerged and solid-state production of laccase and Mnperoxidase by Panus tigrinus on olive mill wastewater-based media. J. Biotechnol. 100(1), 77-85.

[64] Fezzani, B., Ben Cheikh, R., 2007. Anaerobic co-digestion of olive mill wastewater with olive mill solid waste in a tubular digester at a mesophilic temperature. Bioresour. Technol. 98, 769-774.

[65] Fezzani, B., Ben Cheikh, R., 2010. Two-phase anaerobic codigestion of olive mill wastes in semi-continuous digesters at mesophilic temperature. Bioresour. Technol. 101(6), 1628-1634.

[66] Fountoulakis, M.S., Dokianakis, S.N., Kornaros, M.E., Aggelis, G.G., Lyberatos, G., 2002. Removal of phenolics in olive mil 
wastewaters using the white-rot fungus Pleurotus ostreatus. Water Res. 36(19), 4735-4744.

[67] Fountoulakis, M.S., Drakopoulou, S., Terzakis, S., Georgaki, E., Manios, T., 2008. Potential for methane production from typical Mediterranean agro-industrial byproducts. Biomass Bioenergy. 32(2), $155-161$.

[68] Galanakis, C.M., Tornberg, E., Gekas, V., 2010. A study of the recovery of the dietary fibres from olive mill wastewater and the gelling ability of the soluble fibre fraction. LWT- Food Sci. Technol. 43(7), 1009-1017.

[69] García, M.L., Cáceres, E., Selgas, M.D., 2007. Utilisation of fruit fibres in conventional and reduced-fat cooked-meat sausages. J. Sci. Food Agric. 87(4), 624-631.

[70] Gassara, F., Brar, S.K., Tyagi, R.D., Verma, M., Surampalli, R.Y., 2010. Screening of agro-industrial wastes to produce ligninolytic enzymes by Phanerochaete chrysosporium. Biochem. Eng. J. 49(3), 388-394.

[71] Gelegenis, J., Georgakakis, D., Angelidaki, I., Christopoulou, N., Goumenaki, M., 2007. Optimization of biogas production from olive oil mill wastewater, by codigesting with diluted poultry manure. Appl. Eng. 84(6), 646-663.

[72] Ghanbari, R., Anwar, F., Alkharfy, K.M., Gilani, A.H., Saari, N., 2012. Valuable nutrients and functional bioactives in different parts of olive (Olea europaea L.)-A review. Int. J. Mol. Sci. 13(3), 3291-3340.

[73] Gigliotti, G., Proietti, P., Said-Pullicino, D., Nasini, L., Pezzolla, D., Rosati, L., Porceddu, P.R., 2012. Co-composting of olive husks with high moisture contents: organic matter dynamics and compost quality. Int. Biodeterior. Biodegrad. 67, 8-14.

[74] Gullón, B., Gullón, P., Eibes, G., Cara, C., De Torres, A., LópezLinares, J.C., Ruiz, E., Castro, E., 2018. Valorisation of olive agroindustrial by-products as a source of bioactive compounds. Sci. Total Environ. 645, 533-542.

[75] Hamdi, M., 1991. Effects of agitation and pretreatment on the batch anaerobic digestion of olive mill wastewater. Bioresour. Technol. 36(2), 173-178.

[76] Hamdi, M., 1993. Future prospects and constraints of olive mill wastewaters use and treatment: a review. Bioprocess Eng. 8(5-6), 209214.

[77] Hamdi, M., Ellouz, R., 1993. Treatment of detoxified olive mill wastewaters by anaerobic filter and aerobic fluidized bed process. Environ. Technol. 14(2), 183-188.

[78] Hamza, M., Khoufi, S., Sayadi, S., 2012. Fungal enzymes as a powerful tool to release antioxidants from olive mill wastewater. Food Chem. 131(4), 1430-1436.

[79] Hill, J., 2009. Environmental costs and benefits of transportation Biofuel Production from Food-and Lignocellulose-Based Energy Crops: A Review, in: Lichtfouse, E., Navarrete, M., Debaeke, P., Véronique, S., Alberola, C. (Eds.), Sustainable Agriculture. Springer, Dordrecht, pp. 125-139.

[80] Iannotti, D.A., Toth, B.L., Elwell, D.L., Keener, H.M., Hoitink, H.A.J., 1993. A quantitative respirometric method for monitoring compost stability. Compost Sci. Util. 1(3), 52-65.

[81] International Olive Council, 2017. List of exporters/importers of olive oils and olive-pomace oils

[82] Jaouani, A., Sayadi, S., Vanthournhout, M., Penninckx, M.J., 2003. Potent fungi for decolourisation of olive oil mill wastewaters. Enzyme Microb. Technol. 33(6), 802-809.

[83] Kalmis, E., Azbar, N., Yildiz, H., Kalyoncu, F., 2008. Feasibility of using olive mill effluent (OME) as a wetting agent during the cultivation of oyster mushroom, Pleurotus ostreatus, on wheat straw. Bioresour. Technol. 99(1), 164-169.

[84] Kapellakis, I.E., Tsagarakis, K.P., Avramaki, Ch., Angelakis, A.N., 2006. Olive mill wastewater management in river basins: A case study in Greece. Agric. Water Manage. 82(3), 354-370.

[85] Kapellakis, I.E., Tsagarakis, K.P., Crowther, J.C., 2008. Olive oil history, production and by-product management. Rev. Environ. Sci. Biotechnol. 7(1), 1-26.

[86] Karpouzas, D.G., Ntougias, S., Iskidou, E., Rousidou, C., Papadopoulou, K.K., Zervakis, G.I., Ehaliotis, C., 2010. Olive mill wastewater affects the structure of soil bacterial communities. Appl. Soil Ecol. 45(2), 101-111.

[87] Kataoka, N., Miya, A., Kiriyama, K., 1997. Studies on hydrogen production by continuous culture system of hydrogen producing anaerobic bacteria. Water Sci. Technol. 36(6-7), 41-47.

[88] Kavvadias, V., Doula, M.K., Komnitsas, K., Liakopoulou, N., 2010. Disposal of olive oil mill wastes in evaporation ponds: effects on soil properties. J. Hazard. Mater. 182(1-3), 144-155.

[89] Khoufi, S., Hamza, M., Sayadi, S., 2011. Enzymatic hydrolysis of olive wastewater for hydroxytyrosol enrichment. Bioresour. Technol. 102(19), 9050-9058.

[90] Kissi, M., Mountadar, M., Assobhei, O., Gargiulo, E., Palmieri, G., Giardina, P., Sannia, G., 2001. Roles of two whiterot basidiomycete fungi in decolorisation and detoxification of olive mill waste water. Appl. Microbiol. Biotechnol. 57(1-2), 221-226.

[91] Kotay, S.M., Das, D., 2008. Biohydrogen as a renewable energy resource: prospects and potentials. Int. J. Hydrogen Energy. 33(1), 258-263.

[92] Kourmentza, C., Koutra, E., Venetsaneas, N., Kornaros, M., 2017. Integrated biorefinery approach for the valorization of olive mill waste streams towards sustainable biofuels and bio-based products, in: Kalia, V., Kumar, P. (Eds.), Microbial Applications Vol. 1. Springer, Cham, pp. 211-238.

[93] Koutrotsios, G., Larou, E., Mountzouris, K.C., Zervakis, G.I., 2016. Detoxification of olive mill wastewater and bioconversion of olive crop residues into high-value-added biomass by the choice edible mushroom Hericium erinaceus. Appl. Biochem. Biotechnol. 180(2), 195-209

[94] Koutsos, T.M., Chatzistathis, T., Balampekou, E.I., 2018. A new framework proposal, towards a common EU agricultural policy, with the best sustainable practices for the re-use of olive mill wastewater. Sci. Total Environ. 622, 942-953.

[95] Laconi, S., Molle, G., Cabiddu, A., Pompei, R., 2007. Bioremediation of olive oil mill wastewater and production of microbial biomass. Biodegradation. 18(5), 559-566.

[96] Lafka, T.I, Lazou, A.E., Sinanoglou, V.J., Lazos, E.S., 2011 Phenolic and antioxidant potential of olive oil mill wastes. Food Chem. 125(1), 92-98.

[97] Lakhtar, H., Ismaili-Alaoui, M.A., Perraud-Gaime, I. Philippoussis, A., Roussos, S., 2010. Screening of strains of Lentinula edodes grown on model olive mill wastewater in solic and liquid state culture for polyphenol biodegradation. Int Biodeterior. Biodegrad. 64(3), 167-72.

[98] Lasaridi, K., Protopapa, I., Kotsou, M., Pilidis, G., Manios, T. Kyriacou, A., 2006. Quality assessment of composts in the Greek market: the need for standards and quality assurance. J. Environ. Manage. 80(1), 58-65

[99] Lesage-Meessen, L., Navarro, D., Maunier, S., Sigoillot, J.C. Lorquin, J., Delattre, M., Simon, J.L., Asther, M., Labat, M., 2001 Simple phenolic content in olive oil residues as a function of extraction systems. Food Chem. 75(4), 501-507.

[100] Liang, T.W., Wang, S.L., 2015. Recent advances in exopolysaccharides from Paenibacillus spp.: production, isolation structure, and bioactivities. Mar. Drugs. 13(4), 1847-1863.

[101] Lin, P.Y., Whang, L.M., Wu, Y.R., Ren, W.J., Hsiao, C.J., Li, S.L. 2007. Biological hydrogen production of the genus Clostridium: metabolic study and mathematical model simulation. Int. J. Hydrogen Energy. 32(12), 1728-1735.

[102] López, M.J., Moreno, J., Ramos-Cormenzana, A., 2001. Xanthomonas campestris strain selection for xanthan production from olive mill wastewaters. Water Res. 35(7), 1828-1830.

[103] López, M.J., Ramos-Cormenzana, A., 1996. Xanthan production from olive-mill wastewaters. Int. Biodeterior. Biodegrad. 38(3-7), 263-270

[104] Magdich, S., Jarboui, R., Ben Rouina, B., Boukhris, M., Ammar E., 2012. A yearly spraying of olive mill wastewater on agricultural soil over six successive years: impact of different application rates on olive production, phenolic compounds, phytotoxicity and microbial counts. Sci. Total Environ. 430, 209-216. 
[105] Mahyudin, A.R., Furutani, Y., Nakashimada, Y., Kakizono, T., Nishio, N., 1997. Enhanced hydrogen production in altered mixed acid fermentation of glucose by Enterobacter aerogenes. J. Ferment. Bioeng. 83(4), 358-363.

[106] Makan, A., Assobhei, O., Mountadar, M., 2014. Initial air pressure influence on in-vessel composting for the biodegradable fraction of municipal solid waste in Morocco. Int. J. Environ. Sci. Technol. 11(1), $53-58$.

[107] Makni, H., Ayed, L., Ben Khedher, M., Bakhrouf, A., 2010. Evaluation of the maturity of organic waste composts. Waste Manage. Res. 28(6), 489-495.

[108] Martirani, L., Giardina, P., Marzullo, L., Sannia, G., 1996. Reduction of phenol content and toxicity in olive oil mill waste waters with the ligninolytic fungus Pleurotus ostreatus. Water Res. 30(8), 1914-1918.

[109] Massadeh, M.I., Modallal, N., 2008. Ethanol production from olive mill wastewater (OMW) pretreated with Pleurotus sajor-caju. Energy Fuels. 150(22), 150-154.

[110] Mercadé, M.E., Manresa, M.A., Robert, M., Espuny, M.J., de Andrés, C., Guinea, J., 1993. Olive oil mill effluent (OOME). New substrate for biosurfactant production. Bioresour. Technol. 43, 1-6.

[111] Mert, B.K., Yonar, T., Kilic, M.Y., Kestioğlu, K., 2010. Pre-treatment studies on olive oil mill effluent using physicochemical, Fenton and Fenton-like oxidations processes. J. Hazard. Mater. 174(1-3), 122-128.

[112] Mili, S., 2006. Olive oil marketing in non-traditional markets: prospects and strategies. New Medit. 5 (1), 27-37.

[113] Minale, M., Worku, T., 2014. Anaerobic co-digestion of sanitary wastewater and kitchen solid waste for biogas and fertilizer production under ambient temperature: waste generated from condominium house. Int. J. Environ. Sci. Technol. 11(2), 509-516.

[114] Moraes, B.S., Zaiat, M., Bonomi, A., 2015. Anaerobic digestion of vinasse from sugarcane ethanol production in Brazil: challenges and perspectives. Renew. Sust. Energ. Rev. 44, 888-903.

[115] Morillo, J.A., del Aguila, V.G., Aguilera, M., Ramos-Cormenzana, A., Monteoliva-Sanchez, M., 2007. Production and characterization of the exopolysaccharide produced by Paenibacillus jamilae grown on olive mill-waste waters. World J. Microbiol. Biotechnol. 23(12), 1705.

[116] Murthy, P.S., Naidu, M.M., 2012. Sustainable management of coffee industry by-products and value addition-a review. Resour. Conserv. Recy. 66, 4-58.

[117] Niaounakis, M., Halvadakis, C.P., 2006. Olive processing waste management: literature review and patent survey. Waste Manage. series, second ed. Elsevier, Amsterdam.

[118] Ntougias, S., Baldrian, P., Ehaliotis, C., Nerud, F., Merhautová, V., Zervakis, G.I., 2015. Olive mill wastewater biodegradation potential of white-rot fungi-Mode of action of fungal culture extracts and effects of ligninolytic enzymes. Bioresour. Technol. 189, 121-130.

[119] Ntougias, S., Gaitis, F., Katsaris, P., Skoulika, S., Iliopoulos, N., Zervakis, G.I., 2013. The effects of olives harvest period and production year on olive mill wastewater properties-Evaluation of Pleurotus strains as bioindicators of the effluent's toxicity. Chemosphere. 92(4), 399-405

[120] Obied, H.K., Allen, M.S., Bedgood, D.R., Prenzler, P.D., Robards, K., Stockmann, R., 2005. Bioactivity and analysis of biophenols recovered from olive mill waste. J. Agric. Food Chem. 53(4), 823-837.

[121] Orive, M., Cebrian, M., Zufía, J., 2016. Techno-economic anaerobic co-digestion feasibility study for two-phase olive oil mill pomace and pig slurry. Renewable Energy. 97, 532-540.

[122] Ouzounidou, G., Ntougias, S., Asfi, M., Gaitis, F., Zervakis, G.I., 2012. Raw and fungal-treated olive-mill wastewater effects on selected parameters of lettuce (Lactuca sativa L.) growth-The role of proline. J. Environ. Sci. Health., Part B. 47(7), 728-735.

[123] Papanikolaou, S., Galiotou-Panayotou, M., Fakas, S., Komaitis, M., Aggelis, G., 2008. Citric acid production by Yarrowia lipolytica cultivated on olive-mill wastewater-based media. Bioresour. Technol. 99(7), 2419-2428.

[124] Paraskeva, P., Diamadopoulos, E., 2006. Technologies for olive mill wastewater (OMW) treatment: a review. J. Chem. Technol. Biotechnol. 81(9), 1475-1485.
[125] Paredes, M.J., Moreno, E., Ramos-Cormenzana, A., Martinez, J., 1987. Characteristics of soil after pollution with wastewaters from olive oil extraction plants. Chemosphere. 16(7), 1557-1564

[126] Pavlidou, A., Anastasopoulou, E., Dassenakis, M., Hatzianestis, I., Paraskevopoulou, V., Simboura, N., Rousselaki, E., Drakopoulou, P., 2014. Effects of olive oil wastes on river basins and an oligotrophic coastal marine ecosystem: a case study in Greece. Sci. Total Environ. 497, 38-49.

[127] Petri, D.F., 2015. Xanthan gum: a versatile biopolymer for biomedical and technological applications. J. Appl. Polym. Sci. 132(23), 42035

[128] Petruccioli, M., Servili, M., Montedoro, G.F., Federici, F., 1988 Development of a recycle procedure for the utilization of vegetation waters in the olive oil extraction process. Biotechnol. Lett. 10(1), $55-60$.

[129] Pinto, G., Pollio, A., Previtera, L., Stanzione, M., Temussi, F., 2003. Removal of low molecular weight phenols from olive oil mil wastewater using microalgae. Biotechnol. Lett. 25(19), 1657-1659.

[130] Piotrowska, A., Rao, M.A., Scotti, R., Gianfreda, L., 2011. Changes in soil chemical and biochemical properties following amendment with crude and dephenolized olive mill waste water (OMW). Geoderma. 161(1-2), 8-17.

[131] Ramírez, I.M., Tsaousi, K., Rudden, M., Marchant, R., Alameda, E.J., Roman, M.G., Banat, I.M., 2015. Rhamnolipid and surfactin production from olive oil mill waste as sole carbon source. Bioresour. Technol. 198, 231-236.

[132] Ramos-Cormenzana, A., Monteoliva-Sanchez, M., Lopez, M.J., 1995. Bioremediation of alpechin. Int. Biodeterior. Biodegrad. $35(1-3), 249-268$.

[133] Rana, G., Rinaldi, M., Introna, M., 2003. Volatilisation of substances after spreading olive oil waste water on the soil in Mediterranean environment. Agric. Ecosyst. Environ. 96(1-3), 4958.

[134] Roig, A., Cayuela, M.L., Sanchez-Monedero, M.A., 2006. An overview on olive mill wastes and their valorisation methods. Waste Manage. 26(9), 960-969.

[135] Ruiz-Bravo, A., Jimenez-Valera, M., Moreno, E., Guerra, V., Ramos-Cormenzana, A., 2001. Biological response modifier activity of an exopolysaccharide from Paenibacillus jamilae CP-7. Clin. Diagn. Lab. Immun. 8(4), 706-710.

[136] Ryckeboer, J., Mergaert, J., Coosemans, J., Deprins, K., Swings, J., 2003. Microbiological aspects of biowaste during composting in a monitored compost bin. J. Appl. Microbiol. 94(1), 127-137.

[137] Rytwo, G., Lavi, R., Rytwo, Y., Monchase, H., Dultz, S., König, T.N., 2013. Clarification of olive mill and winery wastewater by means of clay-polymer nanocomposites. Sci. Total Environ. 442 $134-142$

[138] Said-Pullicino, D., Gigliotti, G., 2007. Oxidative biodegradation of dissolved organic matter during composting. Chemosphere. 68(6), 1030-1040.

[139] Salido, S., Pérez-Bonilla, M., Adams, R.P., Altarejos, J., 2015. Phenolic components and antioxidant activity of wood extracts from 10 main Spanish olive cultivars. J. Agric. Food Chem. 63(29), 6493-6500.

[140] Sarris, D., Matsakas, L., Aggelis, G., Koutinas, A. A. Papanikolaou, S., 2014. Aerated vs non-aerated conversions of molasses and olive mill wastewaters blends into bioethanol by Saccharomyces cerevisiae under non-aseptic conditions. Ind. Crops Prod. 56, 83-93.

[141] Sarris, D., Stoforos, N.G., Mallouchos, A., Kookos, I.K., Koutinas, A.A., Aggelis, G., Papanikolaou, S., 2017. Production of addedvalue metabolites by Yarrowia lipolytica growing in olive mil wastewater-based media under aseptic and non-aseptic conditions. Eng. Life Sci. 17(6), 695-709.

[142] Scoma, A., Bertin, L., Zanaroli, G., Fraraccio, S., Fava, F., 2011. A physicochemical-biotechnological approach for an integrated valorization of olive mill wastewater. Bioresour. Technol. 102(22), 10273-10279.

[143] Shahidi, F., Naczk, M., 2003. Phenolics in food and nutraceuticals CRC Press, Boca Raton, FL, USA. 
[144] Shekhar, S., Sundaramanickam, A., Balasubramanian, T., 2015. Biosurfactant producing microbes and their potential applications: a review. Crit. Rev. Env. Sci. Technol. 45(14), 1522-1554.

[145] Singh, H., 2006. Mycoremediation: Fungal Bioremediation. John Wiley \& Sons Inc., New Jersey, USA. 357-375.

[146] Sutherland, I.W., 1998. Novel and established application of microbial polysaccharides. Trends Biotechnol. 16(1), 41-46.

[147] Tanisho, S., Kuromoto, M., Kadokura, N., 1998. Effect of $\mathrm{CO}_{2}$ removal on hydrogen production by fermentation. Int. J. Hydrogen Energy. 23(7), 559-563.

[148] Therios, I., 2009. Olive Mill Products and Environmental Impact of Olive Oil Production, in: Atherton, J. (Ed.), Olives. CABI, Thessaloniki, pp. 295-302.

[149] Tsioulpas, A., Dimou, D., Iconomou, D., Aggelis, G., 2002. Phenolic removal in olive oil mill wastewater by strains of Pleurotus spp. in respect to their phenol oxidase (laccase) activity. Bioresour. Technol. 84(3), 251-257

[150] Toyota, K., Kimura, M., 2000. Microbial community indigenous to the earthworm Eisenia foetida. Biol. Fertil. Soil. 31(3-4), 187-190.

[151] Tziotzios, G., Michailakis, S., Vayenas, D.V., 2007. Aerobic biological treatment of olive mill wastewater by olive pulp bacteria. Int. Biodeterior. Biodegrad. 60(4), 209-214.

[152] Uyar, B., Kars, G., Eroğlu, İ., Yücel, M., Gündüz, U., 2012. Hydrogen production via photofermentation, in: Azbar, N., Levin, D.B. (Eds.), State of the art and progress in production of biohydrogen. Bentham Science Publishers, United Arab Emirates, pp. 54-77.

[153] Vinciguerra, V., D’Annibale, A., Delle Monache, G., Sermanni, G.C., 1995. Correlated effects during the bioconversion of waste olive waters by Lentinus edodes. Bioresour. Technol. 51(2-3), 221-226.
[154] Visioli, F., Poli, A., Galli, C., 2002. Antioxidant and other biological activities of phenols from olives and olive oil. Med. Res. Rev. 22(1), 65-75

[155] Vivas, A., Moreno, B., Garcia-Rodriguez, S., Benítez, E., 2009 Assessing the impact of composting and vermicomposting on bacterial community size and structure, and microbial functional diversity of an olive-mill waste. Bioresour. Technol. 100(3), 13191326.

[156] Vossen, P., 2013. Growing olives for oil, in: Aparicio, R., Harwood J. (Eds.), Handbook of olive oil: Analysis and properties. Springer, New York, pp. 19-56.

[157] Yay, A.S.E., Oral, H.V., Onay, T.T., Yenigün, O., 2012. A study on olive oil mill wastewater management in Turkey: a questionnaire and experimental approach. Resour. Conserv. Recycl. 60, 64-71.

[158] Yousuf, A., Sannino, F., Addorisio, V., Pirozzi, D., 2010. Microbia conversion of olive oil mill wastewaters into lipids suitable for biodiesel production. J. Agric. Food Chem. 58(15), 8630-8635.

[159] Zerva, A., Zervakis, G.I., Christakopoulos, P., Topakas, E., 2017. Degradation of olive mill wastewater by the induced extracellular ligninolytic enzymes of two wood-rot fungi. J. Environ. Manage. 203, 791-798

[160]Zorpas, A.A., Costa, N.C., 2010. Combination of Fenton oxidation and composting for the treatment of the olive solid residue and the olive mill wastewater from the olive oil industry in Cyprus. Bioresour. Technol. 101(20), 7984-7987.

[161]Zucconi, F., Monaco, A., Forte, M., De Bertoldi, M., 1985 Phytotoxins during the stabilization of organic matter, in: Gasser, J.K.R. (Ed.), Composting of agricultural and other wastes. Elsevier, London, pp. 73-86. 